\section{Are Men Benefiting from the New Economy?}

\author{
Male Economic Marginalization in \\ Argentina, Brazil, and Costa Rica
}

Omar Arias
Have economic reforms in Latin America led to a deterioration in men's ability to be economically selfsufficient? Household survey data on unemployment and real wage growth for distinct groups of male workers in 1988-97 show no evidence of a general trend of male economic marginalization.

The World Bank

Latin America and the Caribbean Region Gender Sector Unit

December 2001 
Policy Research Working Paper 2740

\section{Summary findings}

The economies of Latin America have undergone extensive reforms, raising concerns about how these changes have affected the labor market. But there is also increasing concern that the reforms may have deeper social ramifications as the new economies strain the ability of certain groups of men to work and to earn good wages, fulfilling their traditional role as providers.

Using household surveys broadly covering the period 1988-97 in urban areas of Argentina, Brazil, and Costa Rica, Arias examines the patterns of unemployment and real wage growth for distinct groups of male workers to see whether there is evidence of a deterioration in men's ability to be economically self-sufficient. He finds no general trend of male economic marginalization.

The incidence and duration of unemployment have increased the most for the typically vulnerable groupyoung, less educated, informal sector workers-but the increased duration of unemployment has also affected older and more educated men. With respect to wages, density and quantile regression analysis indicates that the usual stories of wage marginalization of vulnerable workers can hardly explain the observed variety of wage growth patterns in the three countries. The positive wage performance has been concentrated mainly in the higher quantiles of the conditional wage distribution. This suggests that differences in unobservable worker characteristics, such as industriousness, labor market connections, and quality of schooling, have been key determinants of the ability of male workers in the region to adapt to economic restructuring.

These results suggest that assistance should be targeted to some groups so that frustrations in asserting an economic identity do not lead to aggressive behavior. But they also show that we must look elsewhere for the roots of the increase in socially dysfunctional behavior.

This paper-a product of the Gender Sector Unit, Latin America and the Caribbean Region-is part of a larger effort in the region to understand the role of gender in developing country labor markets. Copies of the paper are available free from the World Bank, 1818 H Street NW, Washington, DC 20433. Please contact Selpha Nyairo, room I8-110, telephone $202-$ 473-4635, fax 202-522-0054, email address snyairo@worldbank.org. Policy Research Working Papers are also posted on the Web at http://econ.worldbank.org. The author may be contacted at omara@iadb.org. December 2001. (42 pages)

The Policy Research Working Paper Series disseminates the findings of work in progress to encourage the exchange of ideas about development issues. An objective of the series is to get the findings out quickly, even if the presentations are less than fully polished. The papers carry the names of the authors and should be cited accordingly. The findings, interpretations, and conclusions expressed in this paper are entirely those of the authors. They do not necessarily represent the view of the World Bank, its Executive Directors, or the countries they represent. 


\title{
Are Men Benefiting from the New Economy? Male Economic Marginalization in Argentina, Brazil, and Costa Rica
}

\author{
by \\ Omar Arias \\ The World Bank \\ LCSPR
}




\section{Introduction}

Since the late 1980s, macroeconomic stabilization in the Latin America and Caribbean (LAC) region has been followed by the acceleration of structural market-based reforms and increasing integration into the global economy. Economic restructuring driven by these so-called "second generation" reforms include trade, fiscal and financial reforms, privatization of public enterprises and provision of some social services, and deregulation of the economy to align prices with market forces. In the transition to a more productive economy, jobs in traditionally protected sectors are replaced by jobs in new more competitive sectors, existing skills become obsolete and sectoral productivity shifts revamp the structure of wages.

While female workers have also been affected (Saavedra, 1999), there is increasing concern that this process may have strained the capability of certain groups of men to fulfill their traditional socially prescribed role as "providers" in the family and thus challenged their self-identity. Barker (1998) reports on research suggesting that men's employment status and earnings affect their decisions about family formation, continuation, and ties to their children. Further qualitative sociological work has linked increasing violence, alcoholism, and substance abuse among some men in the region to the challenges that economic changes pose to their "breadwinner" role (Barker, 1998).

Although often focused on non-randomly-selected vulnerable male subpopulations (e.g., low-income young men), this sociological research alludes to overall trends of declining male labor force participation, and increasing unemployment or wage deterioration of these specific groups as evidence of economic intramale marginalization. However, it has not been carefully ascertained whether or not this presumed male economic marginalization is indeed an economy-wide phenomenon. In fact, the standard economic theory (e.g., Hecksher-Ohlin) behind ongoing reforms predict that more vulnerable workers (ie., the unskilled) should benefit the most. Although contrary evidence points to an increase in wage inequality in many Latin American countries during the $1980 \mathrm{~s}$ and early $1990 \mathrm{~s}^{1}$, trends in recent years have been less researched. Moreover, while unemployment is a cause of increasing concern and, overall, real wages have been on the rise in most of the region in the 1990s, little work has focused on changes in intramale differentials. More micro-level research is thus needed to carefully examine the hypothesis of intra-male marginalization during recent economic restructuring in various countries in the region.

In this study we use evidence from available household surveys broadly covering the period 1988-97 in urban areas of Argentina, Brazil and Costa Rica. We carefully examine the following questions: 1) Is there evidence of deterioration in the income generation capacity of certain groups of men? 2) Have certain groups of men lagged behind in accruing any of the wage growth entailed by economic reforms? 3) What are their socioeconomic and labor market characteristics?.

Although we characterize employment and unemployment patterns, we mainly rely on a very detailed analysis of changes in the wage structure in these countries.

${ }^{1}$ See for example Robbins (1997) and Cragg and Epelbaum (1996). 
Wages are a key determinant of labor force participation, incomes, and poverty, and are the ultimate indicators of the quality of jobs in reforming economies.

We examine changes in the whole distribution of wages and not just average wage trends. Specifically, we characterize changes in the wage distributions of distinct groups of workers using kernel density estimation and quantile methods. We are especially interested in the evolution of real wages of those "typical" individual males located at the bottom quantiles of the wage distribution, particularly workers who earn wages lower than predicted by their demographic characteristics and observable levels of skills. A focus on "average" wage trends may obscure the particular conditions that affect these men.

One of our main findings indeed suggests that positive wage performance has been mainly concentrated at the higher quantiles of the conditional wage distribution. The dynamics generating wage gains for particular groups or workers employed in the expanding sectors have often eluded workers in the less privileged jobs, that is, those earning wages lower than predicted by measured characteristics. Thus the unobservable heterogeneity that varies across groups of workers (e.g., differences in ability, labor market connections, quality of schooling) affects non-trivially the capacity to adapt to economic restructuring and thus can generate differences in labor market performance. While the analysis does not attempt to establish causal connections with reforms and other parallel changes in these economies, it offers a richer characterization of recent wage trends and pinpoints which groups of men have lost or won. This is of critical importance for the design of equity-enhancing policies and safety nets to protect workers excluded during economic transitions with potential added social benefits in crime and violence reduction.

The paper is organized as follows. Section 2 discusses the choice of countries and time periods, and briefly describes the main economic reforms and economic performance of each country. Section 3 describes the methodology and the data. Section 4 characterizes overall trends in male labor market outcomes, specifically trends and patterns of male employment, unemployment and real wages. Section 5 discusses quantile wage regression results. Section 6 concludes and suggests some policy implications.

\section{Background: Reforms and Economic Performance}

Although structural reforms have dominated policymaking in virtually all economies in the region since the mid-1980s, there are important differences in the intensity, pace and degree of success. We focus on the experiences of Argentina, Brazil and Costa Rica to study intramale economic marginalization. ${ }^{2}$ As in most of the region, policy reform in these three countries has aimed to stabilize and provide a long-term solution to macroeconomic crises characterized by historically high rates of inflation, fiscal and trade deficits and economic decay. Nevertheless, they illustrate some of the

\footnotetext{
${ }^{2}$ The original design also included Colombia to attempt exploring indigenous issues and connections to violence, and the Dominican Republic to illustrate a Caribbean experience. Unfortunately, we could not obtain the relevant labor survey data timely.
} 
regional diversity in reform experiences, from the early but gradual Costa Rican process, the swift and sustained Argentine program, and the stop-go nature of the Brazilian reform approach. Furthermore, these countries capture some of the considerable diversity in economic structure across the region, from the relatively large industrial sectors with a relatively skilled labor force in Argentina and a less skilled workforce in Brazil, to the smaller scale maquilas, bigger service orientation, and continuing welfare state tradition that backs a well educated labor force in the small Costa Rican economy.

We consider two years covering a period of more intense reform efforts, specifically the periods 1988-97 for Argentina, and 1989-95 for Brazil and Costa Rica. Although some began earlier (in the mid-late 1980s), economic reforms were introduced or deepened to varying degrees during these periods. Although this only allows a rough snapshot of the labor markets in two points in time, these years take into account the general trends during the periods. They are also chosen to control for business cycle fluctuations (as measured by GDP growth and inflation trends) and maximize data comparability both within and across countries. ${ }^{3}$

Here we briefly outline the major macroeconomic changes and reforms that operated in the three economies during these periods. Rather than a comprehensive account, we focus on the key developments that may have affected labor markets. ${ }^{4}$

\section{Argentina}

The cornerstone of the Argentine economic policy program during the period was the convertibility plan. The key to this plan, introduced in 1991, was a new monetary system based on a fully convertible exchange rate regime which fixed the rate of the Argentine peso at 1:1 to the US dollar and abolished all capital and exchange controls. It also comprised a wide variety of structural adjustment measures including public sector, trade, and financial reforms that were accompanied by a massive program of privatization and deregulation of the economy. For instance, from the late 1980s to 1991 the average protection of tariffs and paratariffs declined from 28 to 15 percent, to a range of $0-22$ percent down from 0-55 percent. ${ }^{5}$ Between 1989 and 1992, a total of 51 firms were privatized and employment in public enterprises declined drastically from 250,000 to 60,000 employees. ${ }^{6}$

According to Pessino (1997) the major developments in the Argentine labor market associated with the implementation of the convertibility plan during this period were: 1) an increase in the relative price of labor with respect to capital, motivated by the

\footnotetext{
${ }^{3}$ We pick 1988 as starting year for Argentina despite the recession because inflation was relatively lower and since the reform program was started in 1991. Both real wages and unemployment rose during 1988-91 and 1991-95, declined during 1995-97, but remained higher in 1997 than during 1988-95 so that a 1997 vs. 1988 comparison reveals the period dominant trend. For a year-to-year analysis of male real wages and unemployment in Argentina, see Arias (1999).

${ }^{4}$ For a comprehensive review of the reform and adjustment process in the region see Edwards (1995) and IDB (1997). For country-specific studies, see for instance World Bank (1996), Report No. 15402-Ar and Pessino (1997) for Argentina, Céspedes and Jimenez (1994) for Costa Rica, and Baer (1995) for Brazil.

${ }^{5}$ Edwards (1995).

${ }^{6}$ op. cit.
} 
elimination of tariffs on capital goods and real appreciation of the peso; 2) an increase in unemployment and underemployment mainly due to slow employment growth but aggravated by the increase in labor force participation, particularly of women; 3 ) technological change, presumably biased towards higher demand for skilled labor; 4) an increase in average labor productivity which, however, has not been sufficient to reduce unit labor costs; and 5) very slow progress in the reform of onerous labor market regulations that block labor mobility and impose high fixed labor costs that constrain labor demand.

The initial success of the plan in quickly moving the economy from historical levels of hyperinflation (1989-90) to remarkable price stability was followed by remarkable sustained economic growth between 1990 and 1994 (around 35\%), was halted by the 1995 recession (-4\%) triggered by the Mexican crisis (the "tequila effect"), but resumed in steady growth between 1995 and 1997 (around 13\%) still with remarkably low levels of inflation and a curbed public sector deficit.

\section{Brazil}

The Brazilian reform process has been distressed by the divergent path of the economy. Despite numerous earlier stabilization plans, in 1990, inflation was still in the triple digits and real GDP declined by 4.6 percent. Structural reforms were introduced parallel to the Collor Plan (1990), Collor Plan II, and a plan of orthodox measures (1992) which attempted to eliminate rapid price increases through some combination of freezes on assets, wages, and prices. These led to a deep recession in 1990-92, followed by a significant recovery in 1993. The Real Plan, of mid-1994, introduced a new currency (the real) and tight monetary policy, and eliminated price and wage indexation, all of which led to a decline in inflation from 5,000 percent per year in the first half of 1994 to 26 percent in 1995, and 11 percent in 1996. The currency stabilization and appreciation triggered a spending boom in 1994-95, which led to GDP growth of $5.8 \%$.

Reforms, again, consisted largely of an opening of the economy, financial deregulation and privatization that accompanied fiscal reform, with no significant attempt at labor market reform. In 1990, under IMF pressure, liberalization was deepened as tariffs fell from an average of $32.2 \%$ in 1990 to $14 \%$ in 1993 , so that from 1987 to 1992 the average degree of protection declined from 80 to $21.1 \%$, with the dispersion reduced from 0-105 to 0-65 percent. Most of the adjustment was completed by 1994. As a result, manufacturing employment declined sharply (37\%) from 1990 to 1996, mostly right after the tariff reduction, although unemployment still remained relatively low $(5 \%){ }^{7}$ The privatization program, in which twenty-two state firms were privatized by 1992, has not been as massive as in other countries in the region (e.g., Argentina). Finally, as a result of financial deregulation, by 1993 interest rates and credit, to a lesser extent, were mostly market determined, and barriers to entry in the financial market had been reduced.

By late 1995, under the fear of growing fiscal and external deficits, the economy began to slow down again, averaging a growth rate of about 3 percent during 1994-97. Fiscal imbalances remained a big problem, which were difficult to address due to the rigidities imposed by the 1988 Constitution (which prohibits laying off public sector

${ }^{7}$ Chamon (1998). 
workers). However, privatization got a second wind in 1996 when public assets worth nearly $\$ 6$ billion were sold, and continued in 1997 with further massive sales of large public enterprises.

\section{Costa Rica}

Although Costa Rica was an early trade reformer, the reform process there has been markedly gradual. It was rooted in the severe crisis that peaked in 1982 with an inflation rate of $90 \%$, a sharp devaluation in the Colon, sizable fiscal and current account deficits, and a 7.3\% real decline in GDP. After tough fiscal adjustment, Costa Rica has positioned itself as one of the best performing economies in the region since 1983, with an annual average growth rate of $4.3 \%$ and a $16 \%$ average rate of inflation between 1983 and 1990.

The key areas of reform have been trade liberalization, fiscal adjustment and financial deregulation. Starting in 1985 , tariffs were gradually reduced to reach an average degree of tariff and paratariff protection of $16 \%$ in 1993 down from $92 \%$, to a range of 5-20 percent down from 1-100 percent. A program was initiated to promote non-traditional exports with incentives such as tax breaks and import duty exemptions. A policy of mini-devaluations of the Colon and lagging of minimum real wages to inflation helped maintain export competitiveness. Free zones and maquilas initiated a slow "hightech" transformation led by the initiation of construction of an Intel subsidiary in 1993. Two bank liberalization laws were passed in 1988 and 1995 that ended the state banks' monopoly and allowed private banks to expand their market share, and further financial restructuring has recently been sought.

Although much progress was made to alleviate the prohibitive external debt service, public sector reform was affected by fragile and intermittent political consensus. It was mainly restricted to transitory measures to curb public expenditure growth and increase tax collection. Privatization of public enterprises and social services has been achieved only in recent years, due in part to the opposition of public sector unions. In 1995 alone, public sector reorganization led to the elimination of 8,000 jobs, a reduction in state subsidies for teachers' pension scheme, and an increase in tax rates. Even progress in trade reform was partially halted by an $8 \%$ increase in tariffs across the board in 1995 as a "temporal" fiscal stabilization measure. As in most of the region, labor market reform has yet to be firmly placed on the policy agenda.

The economy continued to exhibit positive growth every year between 1990 and 1995 (averaging 4.5\%), especially during 1992-93, notwithstanding inflation (average of $20 \%$ per year) and growing fiscal and current account deficits that worsened the already delicate external debt situation. In 1995, fiscal restraint within an IMF stand-by agreement led to a decline of $0.6 \%$ in growth, although inflation remained high at $17.5 \%$. Growth resumed in 1997 (3.2\%) with a deceleration in inflation to $13.5 \%$. Unemployment remained rather low throughout the period, especially when compared with regional trends of rising unemployment. 


\section{Methodology and Data}

\subsection{Methodology}

Often, "marginalization" (of a given subpopulation) is associated with various manifestations of poverty such as a high proportion of unsatisfied basic needs or insufficient income to purchase a basket of basic goods and services. In this paper, we focus directly on changes in male income generation capability to examine the hypothesis of intramale economic marginalization. Clearly, this depends on the ability to secure stable and good quality employment.

Overall, economic reforms bring the promise of enhancing the economy's potential to generate new jobs and higher real wages through labor productivity boosts. More efficient labor markets are expected to create productive employment that simultaneously raises living standards for workers and improves firms' competitiveness. However, it is very difficult to accurately predict and measure the impact on specific labor market outcomes of the set of reforms implemented in these countries.

First, alternative explanations yield opposing theoretical predictions depending on specific country characteristics related to initial endowments and characteristics that affect internal markets operation. For instance, standard trade theory (e.g., HeckscherOhlin and Stolper-Samuelson) predicts that trade liberalization in developing countries should increase the relative wages of unskilled (the abundant factor) relative to skilled workers. However, it is also argued that the technological change that comes with increased openness is biased against unskilled labor and thus augments skill wage premiums. The evidence on this is far from conclusive. ${ }^{8}$ Second, other reforms may have countervailing effects. For instance, labor market deregulation (e.g., reduction in the power of unions or minimum wage coverage) may eliminate wage rents enjoyed by specific groups of workers.

Most crucially, the net benefits of reforms are fully granted only in the long run. In the transition, some job destruction takes place and real wages must adjust to changing patterns of demand and skills scarcity. Certain workers may end up bearing most of the cost of adjustment through higher and persistent unemployment or employment in jobs of lower real compensations and may be further excluded from the growth-enhancing benefits of reforms. Given the relatively short spans of time considered, examination of such transition or perhaps more permanent outcomes is what we aim at here.

Specifically, to address the question posed above, we analyze the incidence and duration of unemployment as well as detail patterns of real wage growth for distinct groups of male workers in the three countries. Although we consider trends in both unemployment and wages, we mainly focus on changes over time in the distribution of wages as our key indicator of intramale economic marginalization. As wages are the prices for different kinds of labor, they are a key determinant of labor force participation, and of current and potential income through the accumulation of assets and human

\footnotetext{
${ }^{8}$ See, for instance, Leamer (1997), Berman, Bound and Machin (1997), Robbins (1997) and Wood (1997)
} for a discussion of the literature and reference to related work for developed economies. 
capital. Moreover, they are the ultimate indicators of the quality of jobs generated by reforming economies.

Conventional analysis of changes in the wage structure typically focuses on changes in average wages for distinct skill groups of workers. For instance, in a regression setting least squares methods can yield (counterfactual) estimates of average wage differentials between workers that differ only in their education levels. Recent empirical work in labor economics has pointed out the limitations of this approach. ${ }^{9}$ Unobservable heterogeneity that varies across groups of workers (e.g., differences in ability, family labor market connections, quality of schooling) is likely to affect labor market performance and the capacity to adapt to economic restructuring in a non-trivial way. For instance, if the creation of new more productive jobs (of a given skill) is sluggish, only those with more spunk or from better connected families may manage to be favorably re-employed in the higher wage jobs, while increased labor redundancy may drive down wages of workers in less favorable jobs.

Therefore, a focus on "average" wage trends may obscure the particular conditions that affect these men. We focus on characterization of changes in the whole distribution of wages rather than on average wage trends. We shall be especially interested in the evolution of real wages of those "typical" individual males located at the bottom quantiles of the wage distribution, or more generally those workers who earn wages lower than granted by their observable levels of skills and demographic characteristics.

For this, we estimate wage densities for several broadly defined groups of male workers and use quantile regression (Koenker and Bassett, 1978) to estimate wage differentials between workers in different points of the wage distribution given observed characteristics. For each year, we estimate regressions of the log of wages on the set of dummy variables for six quantiles $(0.05,0.1,0.25,0.5,0.75,0.9)$ and two different specifications. ${ }^{10}$ Conventional least squares (mean) regressions are obtained for reference and often yield results similar to median regression. The change in the resulting "adjusted" quantile wage differentials across the two periods are compared with the "raw" real wage growth rates obtained from a simpler age-education cell analysis. These are then used to identify male workers whose wages are lagging behind in the new economy along the entire wage distribution.

The analysis contrasts the evolution of wages across workers that differ in their endowment of general (education, experience) and specific (industry, occupation) skills and in demographic factors which influence wages (race, marital/headship status). An important characteristic of labor markets in the region is that a large segment of the workforce is "informal", that is, operates outside formal regulatory structures. Often seen

\footnotetext{
${ }^{9}$ See for instance Buchinsky (1994), Mwabu and Schultz (1996), Arias, Hallock and Sosa (1999), Machado and Mata (1999), Maloney and Ribeiro (1999).

${ }^{10}$ All the estimations and tests were carried out in Splus V. 4.5. In Brazil quantile regressions are estimated using recently developed interior point algorithms due to the large sample sizes. All the reported test statistics are based on related regression rank score procedures. See Appendix II for a brief description of the techniques. Koenker and Portnoy (1997) for a detailed discussion of quantile methods.
} 
as a repository of workers unable to find employment in the formal sector who often have to cope with lower wages, this sector includes the self-employed (cuenta propia) and workers in small firms lacking social protection schemes such as health insurance and work benefits, albeit there is no consensus on precise definitions. Although this view has recently been challenged, ${ }^{11}$ we also contrast the evolution of informal and formal wages as another potential dimension of intramale economic marginalization ${ }^{12}$.

Overall, we shall interpret as key evidence of wage marginalization: 1) a systematic decline in the level of wages of a given group of workers relative to overall wage trends, and 2) a change in the wage distribution, not compensated by an increase in wage levels, that increases the proportion of workers (in the population or within a given group) in low-wage jobs.

We do not attempt to address the considerably more difficult task of sorting out the causal factors underlying the observed labor market outcomes. This would require a rather different approach. The results below do provide a rich account of key trends that require further exploration in future research.

\subsection{Data}

We use available data from national household surveys covering urban areas for each initial and end year in the relevant periods. These are the Encuesta Permanente de Hogares (EPH) in Argentina (1988, 1997) covering Greater Buenos Aires, the Pesquisa Nacional por Amostra de Domicilios (PNAD) in Brazil and the Encuesta de Hogares de Propósitos Múltiples (EHPM) in Costa Rica $(1989,1995) .^{13}$

The analysis only considers males who report being salaried workers or self-employed (cuenta propia) and age 15 to 70, thereby excluding owners of small firms and unpaid family workers. ${ }^{14}$ The wage analysis is based on hourly wages for men who report a positive number of hours of work and earnings in the main occupation. Real wages are computed in 1988 pesos in Argentina, 1989 pesos in Costa Rica, and 1989 US dollars in

\footnotetext{
${ }^{11}$ See Maloney (1998a, 1998b) for a discussion of the labor market segmentation hypothesis in LDCs.

${ }^{12}$ Regressions are run on the pooled sample of salaried and self-employed workers. Although this restricts sectoral wage differentials to be independent of observable characteristics, it allows a direct assessment of the relative wage performance of workers across sectors after adjusting for such characteristics. Moreover, the smaller sizes of the informal samples may result in noisier statistical inferences.

${ }^{13}$ In Argentina, we merge the May and October waves of the EPH surveys in each year to obtain bigger sample sizes. In Brazil, the 1995 PNAD does not allow to distinguish between urban and rural areas. In order to enhance comparability over time, the 1995 sample for Brazil covers only the largest metropolitan centers (Rio, Sao Paulo, Minas Gerais, Paraná, Pernambuco, Bahía and Ceará) and exclude agricultural workers. For Costa Rica we only include individuals living in metropolitan areas.

${ }^{14}$ The relevant population for inference purposes is the employed male population, which may or may not be representative of the whole male population of workers in the labor force (including the unemployed). However, biases arising from self-selection into the labor force are typically not as big a concern for men as for women. Atternpts to correct for self-selection into to the labor force or for correlation between unobservable determinants of unemployment spells and wage equation regressors using parametric sample selection methods (e.g., Heckman, 1979) are increasingly recognized as unsatisfactory due to the sensitivity of the approach to statistical assumptions.
} 
Brazil. ${ }^{15}$ We drop observations with inconsistent income reports and missing data on any of the variables of interest. ${ }^{16}$

Worker characteristics are captured by dummy variables to facilitate isolating changes in counterfactual wage distributions for narrowly defined groups based on human capital attributes such as age, education, occupational skills and tenure (only in Argentina), job characteristics as captured by category ${ }^{17}$ and sector of employment, and other regional (except Argentina) and demographic controls (i.e., marital and headship status, and race in Brazil). ${ }^{18}$ In the central specification ${ }^{19}$, which is based on nine ageeducation (skill) groups, the comparison (control) groups used to assess relative wage performance correspond to single, white (in Brazil), non-head, professional workers older than 45 with college or more, more than 10 years of tenure (in Argentina), employed in financial/business services and formal sector firms. In Brazil and Costa Rica, the richest region is used as base (Southeast and Central, respectively).

\section{Overall Labor Market Trends}

We first briefly describe the main trends in male labor market outcomes in each country. ${ }^{20}$ We begin with changes in the patterns of labor force and sectoral participation, and changes in the characteristics of the work force by sector of employment. We then examine the incidence and duration of unemployment as well as real wage changes for broad age and education groups.

\subsection{Labor Force Participation and Work force Characteristics}

Table 1 presents statistics on male labor force and sectoral participation by groups of workers in the three countries. Overall, labor force participation increased in Argentina and Costa Rica and declined in Brazil during the relevant periods, but the changes are all less than 1 percentage point. Less than half of younger men (age 15-20) participate in Argentina and Costa Rica, and a somewhat higher proportion does in Brazil. Their participation declined in Argentina and Brazil, presumably as a result of more continuity in schooling, but increased slightly in Costa Rica. Participation of those age 20-25 is considerably higher and increased significantly in Costa Rica and Argentina but declined in Brazil. Virtually all middle-age men (prime age and age 35-45)

\footnotetext{
${ }^{15}$ We use national currencies to avoid the measurement problems that trade imbalances (which often pervaded in these economies) may cause to US dollars conversions. However, due to the numerous changes in currency in Brazil during the period of hyperinflation the US dollar translation was deemed more appropriate. IPCs are used to obtain real values.

${ }^{16}$ Estimates of labor market statistics were not significantly affected by exclusion of these non-responses.

${ }^{17}$ This measures differences in wages across sectors that are unaccounted by observable characteristics. However, as stressed by Maloney (1998a, 1998b), these cannot be interpreted as evidence of existence of a dual labor market. Earnings differentials arising from different taxation, unobservable entrepreneurial ability, tastes differences are all likely to affect individual sectoral choices of employment and this effect can be confounded with any "true" sectoral differences in earnings.

${ }^{18}$ See Appendix I for precise definitions of all variables across countries.

${ }^{19}$ The second specification, not discussed further, differentiates between complete and incomplete degrees but do not use age-education interactions. Workers age 35-45 with college or more serve as a control group. This is not discussed further since the results are consistent with those reported here.

${ }^{20}$ Saavedra (1999) characterizes overall trends in female labor market outcomes.
} 
participate steadily. Interestingly, participation rates increased in all three countries for older men (age 45.70), notably in Argentina, in part due to an increased retirement age. Both men with a primary education or less and those with higher education significantly increased their participation in Argentina and Costa Rica, and reduced it in Brazil. The participation of men with secondary education changed very little.

Consistent with regional trends, in all three countries these labor force participation trends have coupled with a shrinkage in the formal sector share of employment, which reflects an increase in the share of informality (defined as informal salaried work and self-employment) in Argentina (by 2-3 percentage points), informal salaried jobs in Costa Rica (by 1 percentage point), and mostly of self-employment in Brazil (from 19\% to 26\%). By the end of the relevant periods, informal employment is largest in Brazil (43\%), followed by Argentina (37\%) and remains much smaller in Costa Rica (30\%).

Table 2 presents statistics describing the composition of employment in each sector according to various worker characteristics. The general skill composition of each sector changes to reflect an increasingly more educated and aging labor force, with some country-specific variation. Formal sector employment is mainly comprised of middle-age (25-45 years) workers with primary and secondary schooling and to a lesser extent higher education. The sector increasingly accommodates more educated (secondary and higher) workers within the middle age group, as well as young workers with college or more in the case of Argentina and Costa Rica. The informal salaried sector is mostly comprised of (any age) workers with primary education and young middle-age workers with secondary education. In Argentina and Brazil, the sector shows a growing preponderance of middle-age workers with secondary education, and in Costa Rica of professionals and workers with higher education. Self-employment is the main sector of choice of middleage and older workers with primary education and middle-age with secondary, but increasingly accommodates more middle-age and older, better educated workers, especially in Argentina.

The data available for Argentina on tenure in occupation indicates that the formal sector increasingly comprises a mix of workers with some experience (less than 5 years of tenure) in their occupation and more experience (more than 10 years), while the informal salaried sector largely comprises new workers (less than one year in current occupation). Self-employment went from being mainly a refuge of more senior workers to comprising mostly new workers with some experience. Data on general labor market experience for 1995 in Brazil are broadly consistent with these patterns, but suggest that sectoral differences in general experience may not be as large. ${ }^{21}$

Formal employment is mainly comprised of manufacturing, public administration and social services, retail and transportation/communication/public utilities. Informal employment is mostly comprised of jobs in retail, construction, manufacturing, and personal services, and a relatively larger share of financial service jobs among the self-

\footnotetext{
${ }^{21}$ This refers to the usual exp $=$ (age-education-6) computation, although here this is based on workers' report of the age they began to work, which is available in the 1995 Brazilian survey.
} 
employed. Shrinking employment in the manufacturing sector, presumably driven by economic reforms, has coupled with rising employment in: a) formal and informal transportation/telecommunication and financial/business services, informal personal services in Argentina, b) formal personal services in Brazil (with informal manufacturing employment changing very little), c) formal retail and financial/business services, informal transportation/telecommunication, social services, and financial/business and personal services in Costa Rica.

\subsection{Unemployment}

Consistent with the region, job creation in Argentina, Brazil and Costa Rica has been considerably sluggish in the 1990s. As shown in Table 1, male unemployment rates increased in all three countries, especially in Argentina where it soared from $5.4 \%$ to $13.4 \%$, followed by Brazil (4.7\% to $7.6 \%$ ) and much less in Costa Rica (4.5\% to 5.8\%). Strikingly, in Argentina the highest increases in unemployment were born by the informal salaried $(6.1 \%$ to $18.3 \%)$ and the self-employed $(7.4 \%$ to $18 \%)$, compared to a rise from $4 \%$ to $8.8 \%$ among the formal salaried. In contrast, the likelihood of becoming jobless increased for formal sector workers in Brazil (4.4\% to $8.4 \%)$ and Costa Rica $(4.8 \%$ to $6 \%$ ), declined for the informal salaried $(6.8 \%$ to $2.6 \%$ and $11.7 \%$ to $10 \%$, respectively), and remained low for the self-employed. ${ }^{22}$

Young (age 15-25) workers account for more than half of the unemployed in all three countries and show a rising probability of unemployment that doubles the national rates, going from $11.2 \%$ to $23.6 \%$ in Argentina, $8.2 \%$ to $14.6 \%$ in Brazil, and $9.4 \%$ to $12.4 \%$ in Costa Rica. Unemployment is also higher and rose among workers with primary education or less in Argentina (6.9\% to $17.7 \%$ ) and Costa Rica (5.2\% to 7\%), and for those with secondary or less in Brazil (5.6\% to $8.5 \%) .^{23}$ In addition, though they still remained lower, unemployment rates among workers with higher education rose more rapidly over the period, becoming four times higher in Argentina, three times higher in Brazil, and twice as high in Costa Rica.

The average ${ }^{24}$ duration of unemployment spells also increased in Argentina (from 10.6 to 20.3 weeks), increased much less in Costa Rica ${ }^{25}$ (62\% of the unemployed remained jobless after 8 weeks, up from 52\%) and decreased in Brazil (from 14.1 to 11.7 weeks). It increased significantly among formal sector workers in Argentina (from 10.6 to 24 weeks) and Costa Rica, but also increased considerably among the informal salaried in Argentina (from 6.4 to 16.6 weeks). The longer durations in Argentina and Costa Rica have not affected the self-employed. Persistent unemployment became even more intense among the elderly in Argentina (14.5 to 24.8 weeks) and Brazil (15.8 to 19.3 weeks), and remained high in Costa Rica (75\% of the elderly unemployed remained unemployed after

\footnotetext{
22 This is based on the unemployed's last sector of employment, which is available in all three country surveys.

${ }^{23}$ This difference may be in part due to differences in the degree structure of the education system in Brazil. See Appendix I for details.

${ }^{24}$ Median durations (not reported) are somewhat lower and change less over time, suggesting a high variance in long- term unemployment spells within age and education groups.

${ }^{25}$ Unemployment duration is coded in week intervals in the Costa Rican survey.
} 
8 weeks). However, unemployment duration increased proportionally more for the young and middle-aged in Argentina and Costa Rica, while it declined for these groups in Brazil. Workers with higher education experienced much longer unemployment spells in Argentina (11.3 to 33.7 weeks) and to a lesser extent Costa Rica, but significantly shorter spells in Brazil.

While hardly surprising, the picture that emerges from the above cross-country trends is suggestive of a systematic strain in the earnings capacity of specific male groups. The well known decline in male labor force participation over the last three decades, presumably driven by higher school enrollment, has slowed down due to higher participation of the elderly. With eroding public pensions under persistent fiscal constraints, this could reflect a need to supplement household incomes with the labor of the elderly.

Unemployment is clearly an overarching expanding problem, especially among the young and less educated, even in Costa Rica where it has long remained a smaller cause for concern. The higher prevalence of joblessness among informal workers in Argentina is surprising but has been found in other work. ${ }^{26}$ Most attention is usually focused on the massive layoffs that are expected from the restructuring of big private firms and public sector retrenchment. But this overlooks the situation of unprotected workers who lose their jobs in small firms that are wiped out by entering national or transnational firms with a larger more efficient scale of operation. Of particular concern is the fact that unemployment duration, which continues to be long for the elderly, is also on the rise for the young (except in Brazil). Therefore young and less educated informal workers appear to be particularly vulnerable to employment fluctuations.

\subsection{Real Wages}

We now examine the behavior of real wages during the relevant periods in each country. Again, the analysis aims at pinpointing specific groups of workers who may have been negatively affected or lagged behind during reform episodes. We first examine general trends focusing on shifts in the entire wage distribution for salaried and selfemployed workers separately. Then we uncover specific trends for broad age, education and occupation groups.

\subsubsection{Overall and Sectoral Changes in Wage Distributions}

Table 3 presents the growth rates per year of different quantiles of the wage distribution in each sector as well as the corresponding sectoral wage differentials, and Figure 1 compares the overall and sectoral wage densities over each period (one column per country).

Some interesting facts emerge from cross-sectoral comparisons. In all three countries, the self-employed wage distribution is notoriously more dispersed and often exhibits rather long tails, reflecting the heterogeneity of the sector. The selfemployed/formal salaried wage gap shrinks monotonically towards the upper tail, turning into a positive wage premium for the high-wage self-employed in Argentina, ultimately

\footnotetext{
${ }^{26}$ Arango and Maloney (1999).
} 
vanishing in Costa Rica, but less so in Brazil. This is consistent with the view of selfemployment as comprising two tiers of workers, a significant fraction earning very low wages and a smaller proportion of workers who are better off. Wages are less dispersed among unprotected workers in small firms and uniformly smaller than wages in other sectors. Thus the growing group of self-employed tends to exacerbate overall wage inequality in these countries. The informal/formal salaried wage differential is higher in Brazil, especially at the upper tail, and rather similar in Argentina and Costa Rica where it is higher at both tails.

Average real wages increased in the three countries, especially in Brazil (3.4\%), and less in Costa Rica (1.1\%), mainly reflecting substantial wage increases for informal salaried workers. However, wage growth was far from uniform both within and between countries.

In Argentina, formal salaried average wages increased the least (1.5\% per year), due to sluggish wage gains of workers earning above the median formal sector wage. In contrast, real wages rose only for workers at the upper tail of the self-employed wage distribution while those in the bottom decile experienced a wage decline or stagnation. The big wage gains of informal salaried workers (avg. 3.9\% per year) were somewhat homogeneous so that their whole wage distribution shifted to the right, except for a sluggish increase at the bottom tail.

In Brazil, the self-employed experienced the smallest average wage gains $(2.3 \%$ per year), mainly reflecting small real wage changes at the upper quartile. Unlike Argentina, those self-employed earning below the self-employed median wage did fairly well. Workers at the upper tail of the formal salaried wage distribution also benefited relatively less. The considerable wage gains of the informal salaried (6.6\% per year) were also the biggest at the bottom tail.

In Costa Rica, the average wage gains of informal salaried workers were much more modest (1.8\% per year), and similar among formal salaried and cuenta propistas. Unlike Argentina and Brazil, real wage growth was highest at the tails in all three sectors, with the self-employed located in the two middle quartiles even experiencing a decline or stagnation in wages.

In sum, not all workers have benefited from the wage bonanza in the three countries, nor have wage gains been uniform. However, usual segmented markets stories are not the key. Many workers in informal jobs, the usual suspected losers, are among those who benefit most. In all three countries, the informal salaried cut the gap with respect to the formal salaried, especially at the upper tail in Argentina and in both tails in Brazil and Costa Rica. The less well off self-employed in Brazil did fairly well, although still lagged behind their analogous formal salaried. Similarly, while the better off selfemployed in Argentina and Costa Rica outperformed their formal salaried counterparts, those less well off continued to lag fairly far behind.

\subsubsection{Group-Specific Wage Growth Patterns}

Figures 2-4 depict, for each country and each year, wage densities for different groups of workers according to age, education and occupational skill. Further contrasting 
patterns of real wage changes emerge across countries. In only a few cases can unambiguous conclusions (uniform shifts) be drawn about the wage performance of any given group within a country.

Although the densities for all age groups generally shifted to the right, except in Costa Rica, the wage bonanza was stronger among young and older workers in Argentina and Brazil. In Costa Rica, the distributions for young and middle-age workers changed little, and that of clder workers shows wage improvements at the tails but a slight wage compression at the middle. Across education groups, Argentine and Brazilian workers with primary education show the more substantial and generalized real wage gains, followed by those with secondary. As a whole, the less educated Costa Rican mostly experienced small wage declines. Meanwhile, the wage performance of workers with higher education is mixed. While in Argentina and Costa Rica the more educated appeared to gain at the tails, the distribution compressed in the middle. No discernible change occurred in Brazil. Finally, all three distributions for occupation groups shifted rightward in Argentina and Brazil, but more so for blue collar workers in Brazil and professionals at the upper tail in Argentina. In Costa Rica, wages declined considerably for workers in the middle of the white collar distribution, barely changed for blue collar, and rose for the better-off professionals. Overall, these distribution trends are consistent with the rise in manufacturing productivity and the good performance of the informal salaried in Argentina and Brazil, the curb in public expenditure and white collar employment and the increasing skill orientation of the maquila-led growth in Costa Rica.

Further conditioning on both education and age readily reveals particular groups that have not benefited from the apparent overall wage bonanza. Table 4 (panels a-b) presents the yearly change in median and mean real wages for nine age-education (skill) groups. Rather than pinpointing a common story, the patterns vary widely both across and within countries, and hint at considerable variance in wage growth experiences.

Focusing on median wages, the big losers in Argentina were formal salaried middle age workers with higher education, followed by self-employed young workers with primary or less and the middle age with some or complete secondary. As indicated above, young informal salaried workers with primary or less were the big winners. Moreover, informal young and older workers with secondary education substantially outperformed the like in formal sector jobs, and similarly for better educated workers in informal jobs, albeit the sample sizes are small.

As suggested before, unexpectedly, the wage bonanza in Brazil eluded workers with higher education almost altogether. Among these, the young self-employed experienced the sharpest median wage decline, followed by older workers in informal salaried jobs and the formal salaried young. In fact, among the better educated only older formal salaried and self-employed workers accrued significant real wage gains. In contrast, the impressive growth of wages of the less educated spilled over all workers regardless of age and sector of employment, although it was more pronounced among the informal salaried. 
The results for Costa Rica indicate that the ambiguous distribution shifts discussed earlier mask mixed patterns of wage performance. The bulk of median wage gains have been markedly concentrated so that instances of real wage deterioration are more common. The hardest hit were older workers with secondary education in all sectors, middle age self-employed with primary or less and the young with some or complete secondary in informal jobs. Like in Argentina, median real wage gains of formal salaried workers with higher education were notable for the young and minor for the middle age. Moreover, the strong wage growth of older informal workers with primary or less contrasts with the wage stagnation of the like formal salaried. ${ }^{27}$

Overall, the picture revealed by this simple wage cell analysis fails to conform with the common presumption that economic reforms have resulted in wide regional trends of steadily rising real wages for highly educated workers in formal salaried jobs, and sluggish or even declining wages for the less educated, especially those in the informal sector. The evidence from Argentina, Brazil and Costa Rica suggests that more intricate patterns of wage growth are at play, which often position disadvantaged workers at the front line of wage gains. Among workers with higher education, only the old formal and self-employed did consistently better across all countries. These are likely to be managers or workers with long tenures and specific human capital such as organizational knowledge that remains valuable in restructuring economies.

It is interesting to note that often both the magnitudes and patterns of wage growth are significantly modified when wage outcomes are assessed based on average (Table 4B) rather than median wages. This is particularly the case in Costa Rica and Argentina. Rather than being driven by outliers ${ }^{28}$ or small cell samples, this points to considerable heterogeneity in wage growth within many age-education groups and sectors. As indicated by the shifts in the group-specific wage distributions, real wage changes were often far from homogeneous. More generally, differences in the distribution of unobservable factors such as individual spunk or school quality are also likely to affect differently the wage performance of observationally equivalent workers so that single measures like the mean or the median would be inappropriate to fully characterize wage performance.

In a spirit similar to the above wage density comparisons, we would also like to explore whether existing wage differentials within "counterfactual" narrowly defined groups have changed any differently over the time period. Obviously, we face severe data limitations to control for even some of the possible interrelations by partitioning workers into many different groups for which wage densities (or even average wages) can be estimated. Quantile regressions provide us with a powerful tool to come close to such characterization by revealing the relative wage performance of more narrowly defined "archetypical" workers. The results of this multivariate quantile analysis below indeed pinpoint important differences in the wage growth experiences of workers at different points of the conditional wage distribution.

\footnotetext{
${ }^{27}$ Results for the more educated workers in informal jobs suggest notorious wage deterioration but are unreliable due to their small number.

${ }^{28}$ Means are computed after trimming $3 \%$ of the observations in the tails within each group.
} 


\section{Wage Quantile Regression Results}

Table 5 presents the change over time in the adjusted wage differentials obtained from the quantile analysis for the age-education specification for each country. ${ }^{29}$ The raw estimated coefficients (with p-values) used in these computations together with mean (OLS) estimates are in Appendix III.

Two remarks can help interpretation of the findings. First, each quantile coefficient has the usual regression interpretation. It measures the difference in the log wages between a worker with the particular characteristic and an otherwise similar worker with the excluded category. For instance, the coefficient on complete secondary education measures the log wage differential between a worker with completed high school and an otherwise similar worker with completed college or more. The anti-log of the coefficient gives the relative wage gap of high school workers with respect to college, adjusting for everything else. ${ }^{30}$

Second, we can think of the different quantiles as pertaining to different "types" of workers located in various points of the distribution of wages for a (counterfactual) group sharing similar characteristics. Thus, the $10^{\text {th }}$ quantile coefficient on complete secondary roughly measures the difference between the corresponding $10^{\text {th }}$ wage percentiles of the secondary and the college groups, adjusting for other factors. Similarly, the $90^{\text {th }}$ quantile coefficient measures the difference between the $90^{\text {th }}$ (conditional) wage percentiles of each education group. The low quantiles can be thought of as pertaining to workers in jobs earning wages lower than granted by their attained education level and other measured characteristics, and the high quantiles to workers in "privileged jobs", that is, those earning wages higher than predicted by observable characteristics. Again, the positioning of workers across different conditional quantiles is more likely related to unobservable heterogeneity such as differences in ability, family labor market connections and/or quality of schooling that varies across groups of workers rather than reflecting merely luck.

Although the precise magnitude of differentials obviously refers to the base group, conclusions about relative wage performance obtained from between group comparisons of changes in estimated wage differentials are clearly independent of the choices of base categories. $^{31}$ The discussion of the results is organized by broad worker characteristics but it is important to stress that they pertain to a conditional analysis where confounding wage effects of the various worker characteristics have been isolated.

\footnotetext{
${ }^{29}$ Due to sample size considerations, in this specification we do not distinguish between completion or not of each level of education. The results for the other specification are fairly consistent and thus reassure that the findings are not biased by small education-age cell sizes.

${ }^{30}$ Letting $b$ denote the corresponding regression coefficient, we have that $\exp (-b)-1$ yields the "return" to college education (Kennedy, 1981). Although the required conditions are rather strong, it is customary to interpret coefficients on $\log$ wage regressions as measures of returns to education.

${ }^{31}$ Our choice of base group seeks direct identification of wage differentials pertaining to workers who, due to their human capital endowment or other characteristics, are more likely to be sensitively affected by economic shocks. The wages of workers in the base categories are also likely to be relatively more stable over time.
} 


\section{Age-Education}

Adjusting for industry, occupation, sector of employment, and other demographics, on average, wage growth has still lagged behind for middle age workers with higher or secondary education in Argentina, the young and middle age with higher education and older workers with secondary in Brazil, and for older workers with secondary, middle age with college or more and the young with primary education in Costa Rica. The best average wage performers continued to be the young with college or more and all workers with primary education (especially the young) in Argentina, all workers with primary education (especially the old) and the young with secondary in Brazil, the young with higher education and older and middle age workers with primary in Costa Rica. However, the changes in wage quantile differentials indicate that wage growth was far from uniform even within these narrowly defined groups.

In Costa Rica and to a lesser extent in Argentina, most of the positive wage performance is mainly concentrated at the higher quantiles of the conditional wage distribution. Adjusting for other factors, the less educated Costa Rican workers (of all ages) lagged notoriously behind at the lower quantiles while similar workers matched or often outperformed the more educated at the high quantiles. Similarly, the high relative wage growth of the young and middle age with higher education mostly reflect the superior progress of those at the high quantiles. In Argentina, other factors considered, wage growth was considerably sluggish for the 10th quantile of young and middle age workers with primary schooling and the more educated young, precisely the groups whose median wage experienced the highest growth.

Interestingly, in Brazil we generally find the reverse patterns. Except for the young with primary, the bulk of wage growth among the less educated is mainly accrued by workers in the lower quantiles. In fact, the relative wage gains of middle age and older workers with secondary education escaped those at the upper quartile (75th quantile and above) of the conditional wage distribution. However, the relatively weak wage performance of young and middle age workers with higher education is less marked among those in the more privileged jobs (i.e., at or above the 90th quantile, adjusting for other factors).

In short, while wage bonanza in Argentina and Costa Rica generally eluded workers at the lowest quantiles (in the less privileged jobs, conditionally), in Brazil these tend to benefit the most.

\section{Occupation and Tenure}

Even adjusting for education and other factors, professionals continued to expand their wage advantage over workers in unskilled (agriculture, blue collar) and relatively skilled (white collar, managers) occupations by an average of roughly $2 \%$ per year in Argentina and Costa Rica, but do not show any apparent average wage growth advantage in Brazil. ${ }^{32}$

\footnotetext{
${ }^{32}$ Although occupational categories differ somewhat across countries, these are still broadly comparable.
} 
However, the quantile results again indicate that this masks important differences in wage growth experiences within occupational groups. Other factors considered, both skilled and unskilled workers did relatively worse at the lower than at the upper quantiles in Argentina. The opposite pattern is observed in Costa Rica where wages of nonprofessionals, especially those in white collar jobs, lagged noticeably behind at the higher quantiles. This may be related to the constraints on public expenditure and employment growth imposed by fiscal rigidities. ${ }^{33}$ Non-professionals at the bottom quartile as well as the unskilled in the upper decile fell relatively behind in Brazil.

Further interesting insights are obtained in Argentina, where data on tenure in the occupation are available. Wages of new workers (less than 1 year) lagged considerably behind those of other workers, especially at the low quantiles. This could be associated with the downward pressure of high unemployment rates on wages for new entrants. Workers with some experience (1-5) did considerably better than those with more seniority in their occupation (5-10 and more than 10, respectively). As a result there was a surge of substantial wage premiums for new workers already located in more steady jobs over new entrants, especially at the bottom quantiles. This may be indicative of the instability of starting salaries of new entrants during economic transitions. It also suggests that adjusting for education, age and other factors, human capital accumulation acquired through labor market experience is proportionally more compensatory of differentials in starting salaries of workers in less privileged jobs.

Thus, the rising wage advantage entailed by specific human capital, particularly for professionals, was generally more visible at the lower quantiles in Argentina and Brazil and at the higher quantiles in Costa Rica. The Argentine evidence further suggests that for any occupational skill level, the premium to human capital accumulated through on-the-job training appears highest for workers that are relatively new in their current occupation, especially those at the lower quantiles.

\section{Sector}

Adjusting for human capital and other worker characteristics cut in half (roughly) the raw informal//formal (IS/FS) average wage differentials in all three countries (in Table 3), while, interestingly, in Brazil the adjusted self-employment/formal (SE/FS) wage gap reveals a significant wage premium for cuenta propistas. Early in each period the IS/FS wage gap shrinks monotonically towards higher quantiles, ranging from $-29 \%$ to $-12 \%$ in Argentina, $-47 \%$ to $-22 \%$ in Brazil, and $-47 \%$ to $-13 \%$ in Costa Rica. Similarly, the $\mathrm{SE} / \mathrm{FS}$ adjusted wage differentials range from $-33 \%$ to $18 \%$ in Argentina, $-15 \%$ to $40 \%$ in Brazil, $-42 \%$ to $27 \%$ in Costa Rica. Thus, as with raw sectoral wage differentials, the adjusted quantile differentials conform to two tiers of informality. The lower seemingly consists of workers with a sizable wage disadvantage, and the upper comprises those with more dynamic earnings, often much higher than formal earnings.

${ }^{33}$ The proportion of white collar workers employed in the public sector declined from $59 \%$ to $50 \%$ during the period. 
Adjusting for other factors, the self-employed did relatively worse in all three countries, specifically those below the third quartile in Argentina and Costa Rica and about all the same in Brazil. The apparent wage advantage of the self-employed changed very little at the top quartile in Argentina and Costa Rica. Meanwhile, the superior wage gains of the informal salaried encountered earlier, appear widely spread only in Brazil and pertain to those in the upper quantile informal jobs in Argentina and Costa Rica. Thus conditional analysis again reveals sluggish wage growth at the lower quantiles among the best (average) wage performers, in this case the informal salaried.

It is then clear that once we adjust for usual wage determinants, self-employed workers in the (conditionally) disadvantaged jobs have lagged systematically behind their salaried worker counterparts. Except for Brazil, those in the more privileged jobs, as judged by their measured characteristics, have maintained their wage advantage. Meanwhile, it appears that the soaring rates of entrance into self-employment in the Brazilian labor market (for both men and women) during the period have constricted shifts of the entire self-employed wage distribution.

\section{Industry}

Some sizable wage differentials arise between workers in different industries that are unexplained by human capital and other worker characteristics. With the notable exception of Brazil, most of these wage differentials become muted by the end of the period.

In Argentina, on average, wages in all sectors but retail grew faster than in the control financial/business services sector. Wages soared in construction, social services and public administration/defense so as to become more closely aligned. In the remaining sectors wage growth has been relatively weak in the middle quantiles. Thus, adjusting for worker characteristics, workers employed in manufacturing and some non-tradables (retail, personal services, communication/transportation/public utilities) did relatively worse or show no advantageous wage improvements at these quantiles. Other factors considered, wages remained the lowest for those employed in retail and personal services.

In Brazil, average wage differentials declined across all sectors, except for transportation/communication/public utilities. ${ }^{34}$ Wages rose relatively faster in some non-tradables (social services, construction, public administration/defense, and personal services). However, except for construction workers, this wage growth is systematically accrued by workers in the upper quantiles. Generally, workers in the bottom quartile did relatively worse or show no advantageous wage growth, including those employed in manufacturing. Although wages became relatively more homogeneous across sectors, they remained significantly lower for workers in retail and personal services and continued to be higher in transportation/communication/public utilities and the financial sector despite their slow growth.

\footnotetext{
${ }^{34}$ Inter-industrial wage differentials are considerably higher in Brazil. However, this is mostly due to the difference in base category. The latter consists only of workers in financial services since we were able to separate these from services to businesses (serv2).
} 
In Costa Rica, wage differentials across industries are significantly smaller and also become more muted by the end of the period. Public employees enjoy wage rents over all other workers. However, it should be noted that, unlike Argentina and Brazil, the definition is not restricted to public administration and defense but more generally refer to the broad public sector. ${ }^{35}$ Public employees and retail workers did relatively worse, with the average wage premium of the former shrinking in almost half. Again, workers in the non-tradables sectors of construction and in social and personal services show the fastest average wage improvement. Much like in Brazil, wage growth in all sectors often eluded workers at the bottom quartile of the conditional wage distribution. In fact, public employees at the upper quartile experienced only a slight decline in their wage premium.

Summarizing, we found that in all three countries wages of retail workers have generally lagged behind. Manufacturing wages are not among the fastest growing. Often disadvantaged sectors (particularly, construction and social services) have experienced the fastest wage growth. Although this led to a general decline in inter-industry wage rents, especially in the tradable sectors, this was less so in Brazil. Workers in retail and personal services continued to earn significantly lower wages. Strikingly, the dynamics generating wage gains in the expanding sectors have not been homogeneous and often elude workers in the less privileged jobs, conditional on measured worker characteristics.

\section{Regional and Demographics}

In most cases, cross country comparisons of wage differentials arising from demographic and regional variation are not possible due to data unavailability. Thus, the race of individuals was only available in Brazil, marital status was not available in the 1989 Brazilian survey, and we can only account for regional differences in Brazil and Costa Rica where by survey design a somewhat wider national representation is granted.

In all three countries, controlling for other factors, married male workers enjoy a wage premiurn over single workers, which except for Brazil is often higher at the lower quantiles. This rose to roughly 11-13 percent in Argentina and Costa Rica, reflecting an increase in the first decile in Argentina and in both tails for Costa Rica. Although unavailable for 1989, it stood slightly higher in Brazil (18\%). There are no significant differences in wages of single workers and those in a consensual union, except for a small premium in Brazil. Heads of non-single headed households did relatively worse than nonheads. While the former enjoyed a wage premium similar to that of married workers, ${ }^{36}$ this declined consistently in all three countries, especially in Argentina.

The faster growth of wages of married male workers contrasts with the well documented decline in the married wage premium in the U.S. There, this has been found to be largely due to a decline in the male productivity effects associated with marriage

\footnotetext{
${ }^{35}$ The Costa Rican survey asks workers explicitly whether they work in the private or public sector. Thus, the public sector dummy should presumably include workers in the decentralized enterprises and Central Bank workers who often earn higher wages. The lower inter-industry wage differentials compared to the other countries may then be due to the purging of public wage effects across all economic sectors.

${ }^{36}$ Presumably, as in the case of married workers, the wage premium for heads also reflects a return to unobserved worker characteristics which grant higher wages.
} 
that followed from a reduction in the average degree of specialization across households as women entered the labor force (Korenman and Neumark, 1991). As reported in Table 1, available data in Costa Rica and Argentina indicate a change in the patterns of family formation, with marriages in relative decline and consensual unions becoming relatively more common. Thus, the rising wage premium for married males may reflect a return to the value of marriage as a sign of personal attributes such as stability and commitment.

In Brazil, black and mulatto workers earn wages substantially lower than granted by measured characteristics (on average, 20 to $25 \%$ less than whites in 1989) while, despite their small number, those with Asian ethnicity enjoy a huge wage premium (an average $28 \%$ more than whites in 1989). The wage disadvantage of black and mulatto workers tends to be higher at the upper quantiles. Over the period, average wages grew relatively more for non-whites, other factors considered. However, progress was generally rather weak for blacks and stronger only at the upper quantiles for mulatos. By 1995 , on average, blacks and mulatos were still earning wages $22 \%$ and $15 \%$ lower than whites, respectively. Asians expanded their wage advantage substantially, especially at high quantiles.

Significant regional differences in wages emerge between the more developed and the less developed regions. Early in the period, workers living in the urban centers of the poorest region in Brazil (northeast) earned on average 24\% less than those in the richest region (southeast). Similarly, in Costa Rica average wages of workers in the poorest regions (Chorotega and Brunca) were $13 \%$ lower than in the most developed region (i.e., San Jose). Over the period, this wage disadvantage continued to expand to other regions, more or less uniformly in Brazil and especially at the lower quantiles in Costa Rica.

In summary, although based on partial evidence, the picture that emerges from the above patterns of wage growth is not very auspicious for workers facing wage disadvantages not explained by human capital or job attributes. Adjusting for other factors, although wages of married workers grew faster, those of heads did not. Since the tendency towards a higher frequency of consensual unions may be more accentuated in poorer households, workers in the latter may have benefited less from overall wage growth. Moreover, the relative wage progress of disadvantaged groups such as black and mulatto workers has been slim, especially for those in the (conditionally) less privileged jobs. Wage differentials that cannot be explained by human capital and other worker and job attributes remain significant. Finally, workers in the less developed regions have benefited less from overall wage growth, especially those who already rank low in the conditional wage distribution.

\section{Conclusions and Policy Implications}

Our findings provide rich empirical evidence to address the three main questions we aimed to examine. We find that the well known regional trends of rising unemployment but better employment quality, as measured by rising real wages, hide patterns of intra-male economic marginalization with varying country intensity, some of which operate rather subtly and thus require finer methodological scrutiny. These are summarized and discussed below. 
With regard to unemployment, although the young are delaying their entry into the labor market, the slow speed of net job creation has affected them the most, especially the less educated, even in countries like Costa Rica where unemployment has remained remarkably low. In all three countries, they are generally twice as likely to be unemployed, and remain jobless for increasingly longer periods in Argentina and Costa Rica. Furthermore, unemployed older workers and those with higher education continued to have greater difficulties in being re-employed. The slow speed of creation of high quality jobs for the rapidly expanding group of workers with higher education and their longer unemployment episodes is worrisome. Not only does it imply that a great deal of skill potential is underutilized, but it may also lead younger workers to question the value of a college education as a means of social mobility.

The findings from the (conditional) wage analysis allow us to construct archetypal male groups who have experienced real wage losses or at best lagged behind. In Argentina: middle age workers with higher education or secondary, non-professionals (especially the blue collar), new entrants and those with longer tenure in their occupations, household heads, and the self-employed in retail and personal services. In Brazil: the young and middle age with higher education and older workers with secondary, non-whites, household heads, self-employed, in transportation, communication and utilities, and living in the less developed metropolitan regions. In Costa Rica: older workers with secondary and the young with primary education, nonprofessionals (especially the white collar), self-employed, retail and public sector workers, and those living in the less developed urban areas. Thus, some general patterns emerge for some non-human capital characteristics while the human capital (education) variables are not so clear cut.

The best average wage performers continued to be the young with college or more and all workers with primary education (especially the young) in Argentina, workers with primary education (especially the old) and the young with secondary in Brazil, the young with higher education and older and middle age workers with primary in Costa Rica. In addition, wage growth has been greater for those who are professionals, those employed in construction and social services, and new workers with some experience (in Argentina).

Although we have not attempted to establish causal connections, the above wage growth patterns are only partially consistent with expected reform outcomes. The predictions of standard Hecksher-Ohlin trade theory are consistent with the stronger wage gains of the less educated in Brazil and Argentina, but not with the poor performance of some of the less educated Costa Ricans. Moreover, workers in non-tradables often experience the most wage gains. Similarly, the evidence contradicts the existence of a systematic skill bias in labor demand due to technical change. Although wages of professionals tend to grow faster than those of unskilled workers, the patterns do not easily break down along educational lines, e.g., the young reaped most of the gains of the college educated workers in Argentina and Costa Rica. Whether or not the cross-country differences relate to the scope, phasing and speed of the reform process in these economies deserves further exploration. 
Thus, our results support the agnosticism with respect to the conventional wisdom linking rising wage inequality with economic reforms (particularly, liberalization) in Latin America. ${ }^{37}$ Overall, the evidence is still inconclusive and may be highly sensitive to the trends. In countries where there is evidence of a worsening of inequality during the period of reforms, it is still unclear whether this is a persistent or transitory phenomenon and what the causes are across the spectrum of countries.

Moreover, the usual stories of wage marginalization of vulnerable (e.g., less educated, young) workers or simplistic segmented market stories are generally at odds with the observed variety of wage growth patterns in the three countries. Our findings conform to two tiers of informality. The lower seemingly consists of workers with a sizable wage disadvantage, and the upper comprises those with more dynamic earnings, often much higher than formal earnings. Although the disadvantaged self-employed do appear to lag behind, often the less educated workers and those in informal salaried jobs appear at the front line of wage gains. The flow of workers to informal salaried jobs, particularly those who end up in the lower wage informal jobs, may be viewed as consistent with the relatively better prospects of wage growth in the sector.

The results also uncover the stringent limitations of the standard mean wage analysis. A novel and striking finding is that in Argentina and Costa Rica most of the positive wage performance is mainly concentrated at the higher quantiles of the conditional wage distribution. Very often, the dynamics generating wage gains for workers from particular groups or in the expanding sectors have eluded workers in the less privileged jobs, that is, those earning wages lower than granted by observable characteristics. This suggests that differences in unobservable worker characteristics such as labor market connections, school quality or industriousness are key determinants of variations in wage performance among workers with the same measured human capital and job attributes. For instance, the rising real wages for the less educated young Argentine workers may have persisted despite the high and persistent unemployment that afflicts their less fortunate equals because jobs in the upper quantiles are hardly accessible to the unemployed so that the downward pressure on wages of redundant labor operate only in the lower quantiles. Although challenging, this is a matter that deserves further exploration.

Our findings call for policy initiatives on different fronts. A revamp of social protection schemes in the region is of utmost priority. To the extent that younger unemployed workers are generally household members and benefit from other family income sources, ${ }^{38}$ they may not warrant the special attention of anti-poverty safety nets. Similarly, workers with higher education tend to have access to more mechanisms to smooth unemployment transitions (i.e., savings, credit and assets). However, the increase

\footnotetext{
${ }^{37}$ Other studies have found evidence of rising wage inequality (e.g., the returns to education becoming steeper) in Brazil, Colombia, Mexico and Venezuela for different time periods (see, for example, the studies by Ferreira and Paes de Barros (1999) in Brazil, Velez, Kugler and Bouillon (1999) in Colombia, Bouillon, Legovini and Lustig (1999) and Cragg and Epelbaum (1996) in Mexico, and Ruprah (1999) in Venezuela.) However, also using data on male workers (excluding the self-employed) in Chile, Montenegro (1999) found that after 1990 wage inequality started to decline.

${ }^{38}$ Less than $20 \%$ of those age $15-25$ are non-single household heads, compared to more than half of the middle age, and the vast majority of older workers.
} 
in the rates of participation of the old may indicate their need to provide or supplement household income with prolonged work. Thus, it may be more effective to target welldesigned unemployment insurance programs mostly to the less educated elderly, to cushion and reduce their longer unemployment spells, and to those of middle age despite their less severe unemployment situation. ${ }^{39}$ Furthermore, the large contribution of informality to the soaring unemployment in Argentina warns that the concerns of massive layoffs resulting from productive restructuring and public sector retrenchment may have left too little attention to the situation of unprotected workers that lose their jobs in small firms wiped out by incoming national or transnational firms operating on a larger more efficient scale. This stresses the well recognized need to find creative mechanisms to extend safety nets to these workers.

Perhaps too much emphasis has been put on disparities in access to education as the main culprit in the rise in wage inequality in some countries. Rising returns for professionals could reflect the scarcity of managers and other workers with specific skills to enact changes during periods of economic transformation. This calls for initiatives to give access to the poor to high quality education and training in specific skills. More importantly, our quantile results strongly suggest that an increase in within-group wage inequality may have been an important contributor to any observed rise in overall inequality. ${ }^{40}$ If part of the quantile difference in wage premiums is due to discriminatory practices or location-specific advantages, other policies are warranted. Discriminatory practices may require changes in existing labor legislation and its application. If access to high quality jobs is determined by information asymmetries (e.g., due to geographic closeness), then a greater effort at disseminating information on available employment opportunities could contribute to more equal access to better jobs among workers from different socioeconomic statuses. Furthermore, the finding of swiftly rising wage premiums for new Argentine workers already located in more steady jobs over workers just entering new occupations (especially at the bottom quantiles) may be indicative of the instability of starting salaries of new entrants during economic transitions. $\mathrm{Re}-$ employment programs targeted to new workers, especially those who tend to have the lowest starting salaries, may offer a very cost-effective means to reduce wage disparities and smooth employment transitions.

Continuing economic restructuring may affect the income generation potential of males and result in more subtle negative impacts on social outcomes and perceptions that should not be ignored. Increasing and persistent unemployment and barriers to high quality employment have likely affected the capacity of some young men and displaced older workers to effect a "breadwinner" role in their current or prospective families (Barker, 1998). The potential link to increasing violence and criminality in the region calls for policy interventions such as progressive programs that help these and older men

\footnotetext{
${ }^{39}$ This is not to say that the young should be excluded from such programs. Efficient considerations may still dictate warranting some coverage (e.g., of household heads) to moderate risk averse behavior and improve job matching.

${ }^{40}$ The results of Montenegro (1999) also indicate that increasing earnings disparities in the eighties may have been in part associated with a large increase in the return to education of workers at the higher quantiles of the (conditional) wage distribution, and to increasing wage dispersion in white collar jobs compared to blue collar (controlling for education and experience).
} 
reflect "about what it means to be men" and find new ways to reaffirm their roles as fathers and partners (Barker, 1998). These may include public support to counseling and mentoring community services and to the creation of spaces for discussions about fatherhood and domestic violence in community organizations. 
TABLE 1: Male Labor Force Participation and Unemployment ARGENTINA BRAZIL COSTA RICA

\begin{tabular}{|c|c|c|c|c|c|c|}
\hline \multicolumn{7}{|c|}{ A. Labor Force Participation Rates (\%) } \\
\hline & 1988 & 1997 & 1989 & 1995 & 1989 & 1995 \\
\hline $15 \leq$ age $<20$ & 42.9 & 37.1 & 67.4 & 63.4 & 46.8 & 47.2 \\
\hline $20 \leq$ age $<25$ & 86.1 & 88.6 & 90.2 & 88.2 & 80.9 & 84.2 \\
\hline $25 \leq$ age $<45$ & 96.8 & 97.3 & 95.6 & 94.7 & 96.6 & 96.2 \\
\hline $45 \leq$ age $\leq 70$ & 74.5 & 79.2 & 70.2 & 71.6 & 78.2 & 79.2 \\
\hline primary & 82.1 & 84.1 & 81.8 & 80.0 & 84.5 & 84.6 \\
\hline secondary & 76.2 & 75.3 & 86.2 & 86.1 & 79.1 & 78.4 \\
\hline university & 80.6 & 82.3 & 90.1 & 86.7 & 79.6 & 84.0 \\
\hline Overall & 80.6 & 81.3 & 84.6 & 83.7 & 81.6 & 82.0 \\
\hline
\end{tabular}

A. Sectoral Participation Rates (\%)

$\begin{array}{lllllll}\text { formal } & 68.0 & 63.0 & 65.0 & 57.0 & 71.0 & 70.0 \\ \text { informal } & 12.0 & 15.0 & 16.0 & 17.0 & 10.0 & 11.0 \\ \text { self-emp. } & 20.0 & 22.0 & 19.0 & 26.0 & 19.0 & 19.0\end{array}$

C. Unemployment Rates (\%)

\begin{tabular}{|c|c|c|c|c|c|c|}
\hline & 1988 & 1997 & 1989 & 1995 & 1989 & 1995 \\
\hline $15 \leq$ age $<25$ & 11.2 & 23.6 & 8.2 & 14.6 & 9.4 & 12.4 \\
\hline $25 \leq$ age $<45$ & 4.1 & 10.1 & 3.9 & 6.9 & 3.0 & 3.5 \\
\hline $45 \leq$ age $\leq 70$ & 3.9 & 11.4 & 2.0 & 4.9 & 2.3 & 3.4 \\
\hline primary & 6.9 & 17.7 & 4.5 & 7.2 & 5.2 & 7.0 \\
\hline secondary & 4.8 & 11.9 & 5.6 & 8.5 & 4.7 & 5.8 \\
\hline university & 2.1 & 8.0 & 1.3 & 3.7 & 1.6 & 3.3 \\
\hline formal & 4.0 & 8.8 & 4.4 & 8.4 & 4.8 & 6.0 \\
\hline informal & 6.1 & 18.3 & 6.8 & 2.6 & 11.7 & 10.0 \\
\hline self-emp. & 7.4 & 18.0 & 1.7 & 2.4 & 2.1 & 2.5 \\
\hline Overall & 5.4 & 13.4 & 4.7 & 7.6 & 4.5 & 5.8 \\
\hline \multicolumn{7}{|c|}{ D. Unemployment Duration } \\
\hline & \multicolumn{3}{|c|}{ Average no. of Weeks } & \multirow[b]{2}{*}{1995} & \multicolumn{2}{|c|}{$\begin{array}{c}\% \text { unemployed } \\
>8 \text { weeks }\end{array}$} \\
\hline & 1988 & 1997 & 1989 & & 1989 & 1995 \\
\hline $15 \leq$ age $<25$ & 9 & 19.3 & 14.3 & 9.1 & 51.7 & 60.2 \\
\hline $25 \leq$ age $<45$ & 9.8 & 17.7 & 13.8 & 11.9 & 42.5 & 49.2 \\
\hline $45 \leq$ age $\leq 70$ & 14.5 & 24.8 & 15.8 & 19.3 & 75.0 & 75.0 \\
\hline primary & 11.1 & 18.6 & 12.6 & 12.5 & 47.6 & 55.6 \\
\hline secondary & 9.4 & 18 & 15.0 & 11.0 & 55.6 & 63.5 \\
\hline university & 11.3 & 33.7 & 21.0 & 13.8 & 50.0 & 65.0 \\
\hline formal & 10.6 & 24.0 & 14.2 & 9.7 & 31.5 & 42.8 \\
\hline informal & 6.4 & 16.6 & 12.0 & 8.9 & 32.3 & 32.5 \\
\hline self-emp. & 12.5 & 12.9 & 11.0 & 10.0 & 30.0 & 26.7 \\
\hline Overall & 10.6 & 20.3 & 14.1 & 11.7 & 50.9 & 59.6 \\
\hline
\end{tabular}


TABLE 2: Characteristics of the Male Work Force (Proportions)

\begin{tabular}{|c|c|c|c|c|c|c|c|c|c|c|c|c|c|c|c|c|c|c|}
\hline & \multicolumn{6}{|c|}{$\Delta$ rrentina } & \multicolumn{6}{|c|}{ Rrazil } & \multicolumn{6}{|c|}{ rnsta Rica } \\
\hline & 19 & 88 & & & 997 & & & 1989 & & & 1995 & & & 198 & & 19 & 95 & \\
\hline & $\mathrm{FS}$ & IS & SE & $\mathrm{FS}$ & IS & $\mathrm{SE}$ & $\mathrm{FS}$ & IS & $\mathrm{SE}$ & $\mathrm{FS}$ & IS & $\mathrm{SE}$ & $\mathrm{FS}$ & IS & $\mathrm{SE}$ & FS & IS & $\mathrm{SE}$ \\
\hline primal & 0.07 & 0.24 & 0.03 & 0.04 & 0.15 & 0.04 & 0.06 & 0.22 & 0.06 & 0.04 & 0.17 & 0.05 & 0.1 & 0.28 & 0.06 & 0.1 & 0.24 & 0.04 \\
\hline prima2 & 0.23 & 0.21 & 0.22 & 0.17 & 0.18 & 0.16 & 0.20 & 0.21 & 0.27 & 0.17 & 0.20 & 0.24 & 0.19 & 0.21 & 0.27 & 0.17 & 0.25 & 0.23 \\
\hline prima3 & 0.18 & 0.15 & 0.23 & 0.14 & 0.14 & 0.23 & 0.11 & 0.11 & 0.25 & 0.10 & 0.10 & 0.22 & 0.11 & 0.14 & 0.29 & 0.1 & 0.11 & 0.27 \\
\hline secun 1 & 0.09 & 0.17 & 0.04 & 0.11 & 0.17 & 0.05 & 0.20 & 0.25 & 0.07 & 0.16 & 0.27 & 0.07 & 0.13 & 0.17 & 0.03 & 0.12 & 0.16 & 0.04 \\
\hline secun2 & 0.19 & 0.11 & 0.24 & 0.23 & 0.18 & 0.19 & 0.27 & 0.14 & 0.23 & 0.32 & 0.19 & 0.27 & 0.24 & 0.13 & 0.19 & 0.24 & 0.14 & 0.2 \\
\hline $\operatorname{secun} 3$ & 0.08 & 0.03 & 0.11 & 0.09 & 0.07 & 0.15 & 0.05 & 0.03 & 0.06 & 0.06 & 0.04 & 0.09 & 0.04 & 0.02 & 0.07 & 0.05 & 0.02 & 0.11 \\
\hline univ1 & 0.03 & 0.04 & 0.01 & 0.05 & 0.04 & 0.01 & 0.01 & 0.01 & 0.00 & 0.02 & 0.01 & 0.00 & 0.02 & 0.02 & 0.01 & 0.04 & 0.03 & 0 \\
\hline univ2 & 0.10 & 0.04 & 0.08 & 0.13 & 0.05 & 0.10 & 0.07 & 0.02 & 0.04 & 0.09 & 0.02 & 0.04 & 0.14 & 0.03 & 0.06 & 0.15 & 0.04 & 0.08 \\
\hline univ3 & 0.03 & 0.01 & 0.04 & 0.04 & 0.02 & 0.06 & 0.02 & 0.00 & 0.02 & 0.03 & 0.01 & 0.03 & 0.02 & 0 & 0.02 & 0.03 & 0.01 & 0.02 \\
\hline manuf & 0.39 & 0.21 & 0.13 & 0.32 & 0.18 & 0.11 & 0.31 & 0.18 & 0.06 & 0.28 & 0.18 & 0.05 & 0.23 & 0.16 & 0.18 & 0.22 & 0.12 & 0.12 \\
\hline const & 0.06 & 0.21 & 0.25 & 0.04 & 0.21 & 0.23 & 0.09 & 0.25 & 0.21 & 0.08 & 0.24 & 0.24 & 0.08 & 0.21 & 0.16 & 0.06 & 0.21 & 0.16 \\
\hline serv1 & 0.12 & 0.08 & 0.08 & 0.15 & 0.11 & 0.11 & 0.11 & 0.06 & 0.09 & 0.12 & 0.08 & 0.09 & 0.12 & 0.06 & 0.06 & 0.11 & 0.10 & 0.12 \\
\hline retail & 0.14 & 0.29 & 0.27 & 0.15 & 0.26 & 0.25 & 0.12 & 0.17 & 0.26 & 0.13 & 0.18 & 0.26 & 0.14 & 0.26 & 0.31 & 0.18 & 0.22 & 0.24 \\
\hline serv2 & 0.08 & 0.04 & 0.06 & 0. & 0.06 & 0.10 & 0.09 & 0.06 & 0.09 & 0.07 & 0.06 & 0.08 & 0.06 & 0.01 & 0.04 & 0.08 & 0.03 & 0.06 \\
\hline socia & 0.07 & 0.03 & 0.05 & 0.08 & 0.03 & 0.04 & 0.03 & 0.03 & 0.02 & 0.03 & 0.05 & 0.02 & 0.28 & 0.03 & 0.02 & 0.23 & 0.05 & 0.03 \\
\hline other & 0.04 & 0.13 & 0.16 & 0.03 & 0.15 & 0.15 & 0.10 & 0.25 & 0.27 & 0.12 & 0.21 & 0.26 & 0.10 & 0.27 & 0.24 & 0.11 & 0.26 & 0.26 \\
\hline public & 0.10 & 0.01 & 0.01 & 0.11 & 0.00 & 0.02 & 0.15 & 0.00 & 0.00 & 0.16 & 0.00 & 0.00 & 0.38 & 0.00 & 0.00 & 0.3 & 0.00 & 0.00 \\
\hline head & 0.68 & 0.46 & 0.78 & 0.62 & 0.44 & 0.70 & 0.63 & 0.41 & 0.76 & 0.66 & 0.44 & 0.75 & 0.65 & 0.39 & 0.78 & 0.62 & 0.41 & 0.74 \\
\hline white & - & - & - & - & - & - & 0.57 & 0.46 & 0.55 & 0.56 & 0.45 & 0.54 & - & - & - & - & - & - \\
\hline black & - & - & - & $\begin{array}{c}- \\
-\end{array}$ & - & - & 0.07 & 0.08 & 0.06 & 0.07 & 0.08 & 0.06 & - & - & - & - & - & - \\
\hline mulato & - & - & - & - & - & - & 0.36 & 0.45 & 0.38 & 0.36 & 0.47 & 0.39 & - & - & - & - & - & - \\
\hline asian & - & - & - & - & - & - & 0.01 & 0.00 & 0.01 & 0.00 & 0.00 & 0.01 & $=$ & - & - & - & - & - \\
\hline skilled & 0.25 & 0.43 & 0.21 & 0.17 & 0.33 & 0.22 & 0.73 & 0.91 & 0.93 & 0.74 & 0.90 & 0.93 & 0.61 & 0.82 & 0.77 & 0.59 & 0.77 & 0.76 \\
\hline unskilled & 0.67 & 0.56 & 0.73 & 0.76 & 0.66 & 0.70 & 0.19 & 0.05 & 0.00 & 0.18 & 0.06 & 0.01 & 0.14 & 0.02 & 0.00 & 0.15 & 0.03 & 0.01 \\
\hline profes & 0.09 & 0.01 & 0.06 & 0.07 & 0.01 & 0.07 & 0.08 & 0.03 & 0.07 & 0.08 & 0.04 & 0.06 & 0.20 & 0.03 & 0.10 & 0.22 & 0.06 & 0.12 \\
\hline agric & - & - & - & - & - & - & - & - & - & - & - & - & 0.05 & 0.12 & 0.13 & 0.04 & 0.14 & 0.11 \\
\hline regl & - & - & - & - & - & - & 0.63 & 0.53 & 0.54 & 0.63 & 0.51 & 0.55 & 0.36 & 0.21 & 0.35 & 0.44 & 0.31 & 0.44 \\
\hline reg2 & - & - & - & - & - & - & 0.12 & 0.08 & 0.11 & 0.11 & 0.10 & 0.10 & 0.22 & 0.27 & 0.24 & 0.22 & 0.22 & 0.19 \\
\hline reg3 & - & - & - & - & - & - & 0.25 & 0.39 & 0.35 & 0.26 & 0.39 & 0.35 & 0.13 & 0.25 & 0.17 & 0.11 & 0.20 & 0.16 \\
\hline reg4 & - & - & - & - & - & - & - & - & - & - & - & - & 0.16 & 0.13 & 0.13 & 0.11 & 0.14 & 0.12 \\
\hline reg5 & - & - & - & - & - & - & - & - & - & - & - & - & 0.13 & 0.15 & 0.11 & 0.11 & 0.12 & 0.09 \\
\hline married & 0.64 & 0.38 & $0.70 \mathrm{C}$ & 0.55 & 0.32 & 0.61 & - & - & - & 0.52 & 0.29 & 0.54 & 0.57 & 0.3 & 0.63 & 0.52 & 0.32 & 0.6 \\
\hline c.union & 0.07 & 0.09 & 0.09 & 0.12 & 0.15 & 0.15 & - & - & - & 0.16 & 0.18 & 0.21 & 0.11 & 0.13 & 0.15 & 0.13 & 0.13 & 0.13 \\
\hline $\exp 1$ & 0.25 & 0.53 & 0.17 & 0.31 & 0.57 & 0.24 & - & - & - & 0.02 & 0.07 & 0.01 & - & - & - & - & - & - \\
\hline $\exp 2$ & 0.29 & 0.31 & 0.220 & 0.31 & 0.27 & 0.30 & - & - & - & 0.08 & 0.17 & 0.04 & - & - & - & - & - & - \\
\hline exp3 & 0.19 & 0.09 & $0.21 \mathrm{C}$ & 0.15 & 0.10 & 0.18 & - & - & - & 0.14 & 0.20 & 0.08 & - & - & - & - & - & - \\
\hline exp4 & $0.2^{\prime}$ & 0.06 & $n$ & 0.22 & 0.06 & 0.28 & - & - & - & 0.75 & 0.5 & 0.88 & - & - & - & - & - & - \\
\hline Sample & 3296 & 565 & 9692 & 2499 & 584 & 884 & 19696 & 4859 & 59212 & 20052 & 6064 & 9306 & 1718 & 233 & 472 & 2165 & 360 & 586 \\
\hline
\end{tabular}

Educi=educ+agei where Prima $=$ some or completed primary; Secun $=$ some or complete secondary education; Univ $=$ some or complete college; Age 1: $=<25$ years, Age2: $25-35$ years, Age3: 35-45 years; Age4: age $\geq 45$; servl=transp./commun./elect.\&water, serv2=finance/real estate/business servs., public=public adm./defense/education, socia= social servs., other=pers. serv./agricult. \& mining; exp $1=$ less 
than 1 year of tenure $(\mathrm{Arg}) \exp .(\mathrm{BR}), \exp 2=1-5$ years, exp3 $=5-10$ years, exp4 $=$ more than 10 years. 
TABLE 3: Real Wage growth and Sectoral Wage Differentials, Men

\begin{tabular}{|c|c|c|c|c|c|c|c|c|}
\hline \multirow{3}{*}{$\begin{array}{c}\text { ARGENTINA } \\
\text { quantiles }\end{array}$} & \multicolumn{4}{|c|}{ Avg. \% growth per year } & \multicolumn{4}{|c|}{ Wage Differentials } \\
\hline & \multicolumn{4}{|c|}{$1997 / 1988$} & \multicolumn{2}{|c|}{1988} & \multicolumn{2}{|c|}{1997} \\
\hline & All & Formal & Informal & self-e & IS/FS & $\mathrm{SE} / \mathrm{FS}$ & IS/FS & SE/FS \\
\hline $5 \%$ & 1.8 & 2.5 & 1.0 & -0.4 & 0.552 & 0.740 & 0.492 & 0.586 \\
\hline $10 \%$ & 1.9 & 2.7 & 4.9 & 0.0 & 0.536 & 0.841 & 0.621 & 0.679 \\
\hline $25 \%$ & 2.6 & 2.6 & 3.9 & 0.4 & 0.643 & 1.007 & 0.700 & 0.844 \\
\hline $50 \%$ & 2.6 & 2.6 & 4.2 & 1.3 & 0.627 & 1.058 & 0.698 & 0.960 \\
\hline $75 \%$ & 1.5 & 1.2 & 3.8 & 1.4 & 0.584 & 1.091 & 0.707 & 1.105 \\
\hline $90 \%$ & 0.9 & 0.5 & 4.6 & 2.9 & 0.489 & 1.097 & 0.666 & 1.332 \\
\hline $95 \%$ & 1.2 & 1.0 & 3.0 & 2.7 & 0.447 & 1.102 & 0.521 & 1.261 \\
\hline Mean & 1.6 & 1.5 & 3.9 & 1.9 & 0.556 & 1.055 & 0.662 & 1.086 \\
\hline \multicolumn{9}{|l|}{ BRAZIL } \\
\hline & \multicolumn{4}{|c|}{$1995 / 1989$} & \multicolumn{2}{|c|}{1989} & \multicolumn{2}{|c|}{1995} \\
\hline quantiles & All & Formal & Informal & self-e & IS/FS & SE/FS & IS/FS & SE/FS \\
\hline $5 \%$ & 7.2 & 4.9 & 12.7 & 6.4 & 0.463 & 0.714 & 0.630 & 0.764 \\
\hline $10 \%$ & 6.0 & 7.9 & 11.9 & 5.9 & 0.544 & 0.884 & 0.634 & 0.811 \\
\hline $25 \%$ & 7.8 & 8.6 & 6.8 & 6.4 & 0.600 & 0.976 & 0.558 & 0.893 \\
\hline $50 \%$ & 6.3 & 6.0 & 9.6 & 3.9 & 0.461 & 1.032 & 0.533 & 0.933 \\
\hline $75 \%$ & 2.9 & 3.4 & 8.9 & 0.9 & 0.385 & 1.026 & 0.491 & 0.900 \\
\hline $90 \%$ & 2.1 & 2.6 & 6.8 & 0.5 & 0.367 & 1.000 & 0.446 & 0.893 \\
\hline $95 \%$ & 2.1 & 2.1 & 4.6 & 2.1 & 0.393 & 0.889 & 0.444 & 0.889 \\
\hline Mean & 3.4 & 3.8 & 6.6 & 2.3 & 0.426 & 0.984 & 0.486 & 0.914 \\
\hline \multicolumn{9}{|c|}{ COSTA RICA } \\
\hline & \multicolumn{4}{|c|}{$1995 / 1989$} & \multicolumn{2}{|c|}{1989} & \multicolumn{2}{|c|}{1995} \\
\hline quantiles & All & Formal & Informal & self-e & IS/FS & SE/FS & IS/FS & SE/FS \\
\hline 5 & 1.3 & 1.0 & 2.8 & 2.3 & 0.479 & 0.593 & 0.528 & 0.635 \\
\hline 10 & 0.9 & 1.5 & 2.0 & 0.5 & 0.547 & 0.734 & 0.564 & 0.694 \\
\hline 25 & 0.2 & 0.6 & 1.5 & -0.5 & 0.591 & 0.820 & 0.623 & 0.768 \\
\hline 50 & 0.8 & 0.7 & 1.4 & 0.1 & 0.603 & 0.901 & 0.630 & 0.874 \\
\hline 75 & 0.7 & 1.1 & 0.8 & 1.9 & 0.552 & 0.896 & 0.540 & 0.935 \\
\hline 90 & 2.1 & 2.0 & 2.2 & 2.8 & 0.493 & 0.976 & 0.501 & 1.019 \\
\hline 95 & 2.7 & 2.0 & 4.3 & 3.5 & 0.463 & 0.964 & 0.520 & 1.039 \\
\hline Mean & 1.1 & 1.2 & 1.8 & 1.1 & 0.550 & 0.916 & 0.569 & 0.911 \\
\hline
\end{tabular}


TABLE 4: Wage Growth Rates (per year) by Male Age-Education Group (\%)

\begin{tabular}{|c|c|c|c|c|c|c|c|c|c|c|c|c|}
\hline \multirow{2}{*}{\multicolumn{2}{|c|}{ A. Medians }} & & & & \multicolumn{3}{|c|}{ BRAZIL } & \multicolumn{5}{|c|}{ COSTA RICA } \\
\hline & & \multicolumn{2}{|c|}{$1997 / 1988$} & & \multicolumn{3}{|c|}{$1995 / 1989$} & & \multicolumn{3}{|c|}{$1995 / 1989$} & \\
\hline & All & formal & informal & self-e & All & formal & informal & self-e & All & formal & informal & self-e \\
\hline primal & 3.3 & 2.9 & 6.5 & -0.1 & 6.8 & 6.3 & 6.0 & 6.3 & -0.2 & 0.1 & -1.8 & -1.5 \\
\hline prima2 & 2.3 & 3.0 & 2.0 & 2.3 & 4.7 & 4.3 & 5.9 & 5.2 & -0.3 & 0.2 & 1.8 & -2.4 \\
\hline prima3 & 2.2 & 2.3 & 2.2 & 0.9 & 7.0 & 7.9 & 11.8 & 5.6 & 0.0 & 0.3 & 6.6 & 1.4 \\
\hline secun 1 & 1.2 & 0.6 & 4.8 & 4.7 & 5.1 & 4.7 & 8.4 & 4.8 & -0.4 & 0.8 & -2.2 & -1.4 \\
\hline secun2 & 0.2 & 1.0 & 0.0 & -0.3 & 2.9 & 3.0 & 6.8 & 2.1 & 0.0 & -0.5 & -0.4 & -0.5 \\
\hline secun3 & 0.9 & 0.1 & 2.5 & 2.2 & 2.7 & 3.6 & 4.2 & 2.1 & -3.5 & -3.6 & - & -2.1 \\
\hline univ1 & 2.4 & 1.8 & 6.1 & - & .1 .8 & -1.9 & 0.9 & -6.8 & 1.7 & 1.5 & - & - \\
\hline univ2 & -1.2 & -1.4 & 4.0 & 0.2 & 0.2 & 0.7 & 0.4 & -1.0 & -0.2 & 0.6 & - & -0.4 \\
\hline univ3 & 1.4 & 2.1 & - & 5.4 & 2.0 & 2.0 & -3.0 & 4.5 & 0.0 & 3.5 & - & - \\
\hline \multirow[t]{2}{*}{ B. Means } & \multicolumn{3}{|c|}{$1997 / 1988$} & & \multicolumn{3}{|c|}{$1995 / 1989$} & \multicolumn{5}{|c|}{$1995 / 1989$} \\
\hline & All & formal & informal & self-e & All & formal & informal & self-e & All & formal & informal & self-e \\
\hline prima1 & 3.5 & 2.7 & 5.9 & 2.9 & 5.0 & 4.4 & 7.8 & 2.0 & -0.4 & 0.2 & 0.1 & -4.0 \\
\hline prima2 & 1.8 & 2.1 & 2.6 & 1.1 & 3.2 & 3.3 & 6.0 & 1.9 & -0.2 & -0.3 & 4.1 & -0.4 \\
\hline prima3 & 1.5 & 1.8 & 2.6 & 0.9 & 5.0 & 5.9 & 8.1 & 2.5 & 1.3 & 0.1 & 5.3 & 2.1 \\
\hline secunl & 1.1 & 0.5 & 2.9 & 3.9 & 2.3 & 2.1 & 5.9 & 0.4 & -0.2 & 0.2 & -0.7 & -6.2 \\
\hline secun2 & -0.4 & -0.2 & -1.0 & 0.0 & 1.2 & 1.2 & 2.8 & 1.1 & 0.0 & -0.5 & 3.9 & 1.6 \\
\hline secun3 & 0.3 & -0.2 & 1.2 & 2.8 & 1.0 & 1.3 & 1.8 & 0.6 & -0.9 & -1.2 & - & -3.3 \\
\hline univ1 & 2.7 & 2.1 & 8.3 & - & 0.0 & 0.1 & -1.6 & -0.6 & 1.5 & 1.9 & - & - \\
\hline univ2 & -1.0 & -1.2 & -1.4 & -0.1 & 0.4 & 0.4 & -0.4 & 0.8 & 0.8 & 0.9 & - & 5.6 \\
\hline univ3 & 0.7 & 0.8 & - & 1.2 & 2.1 & 2.0 & -1.1 & 4.3 & -2.3 & -0.9 & - & - \\
\hline
\end{tabular}

- small sample sizes. 
Figure 1: Comparisons of Distributions of Real Wages by Sector of Employment

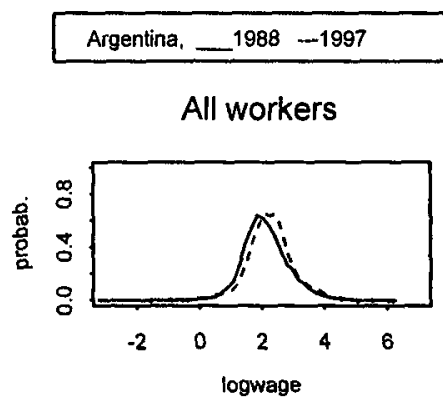

formal

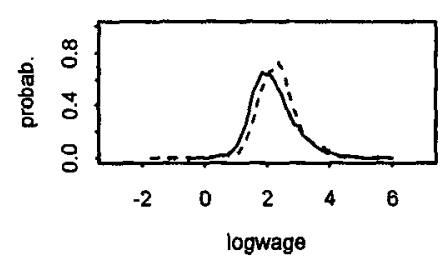

informal

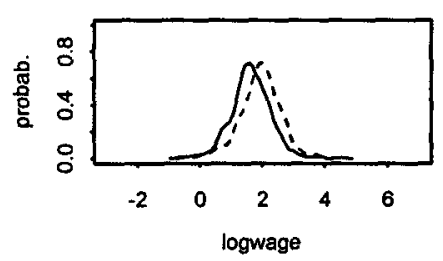

self-employed

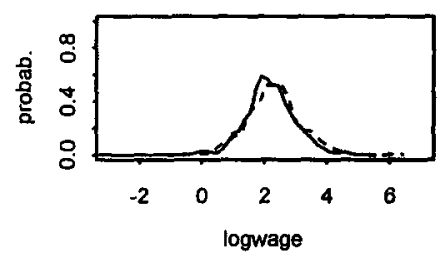

$$
\text { Brazil. __ } 1989-1995
$$

All workers

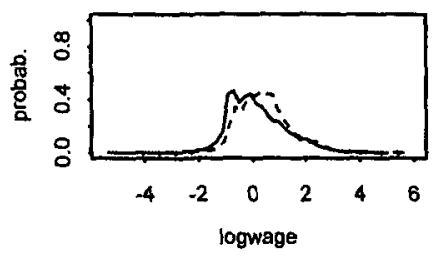

formal

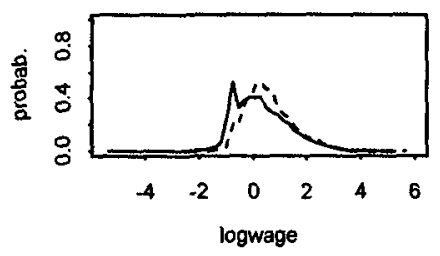

informal

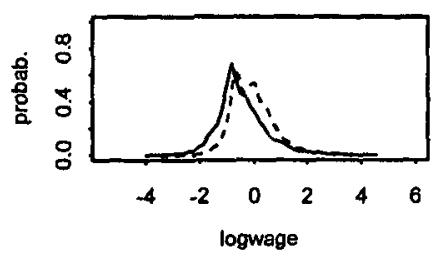

self-employed

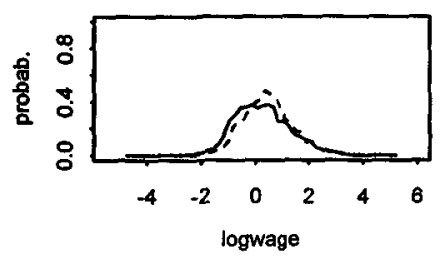

Costa Rica, __ $1989-1995$

All workers

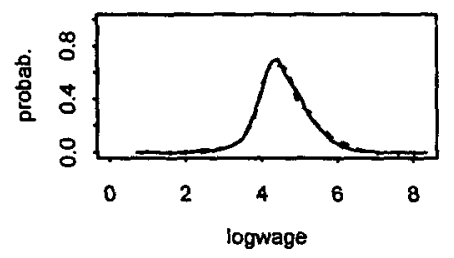

formal

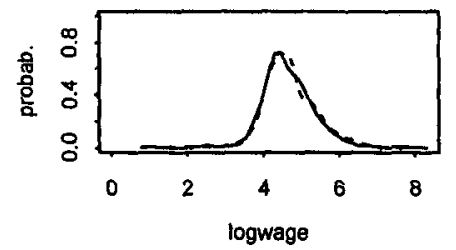

informal

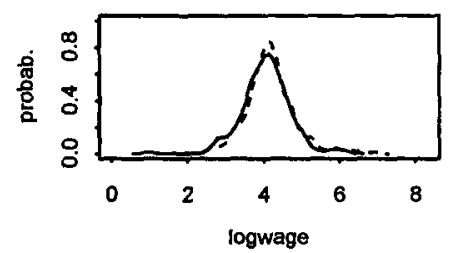

self-employed

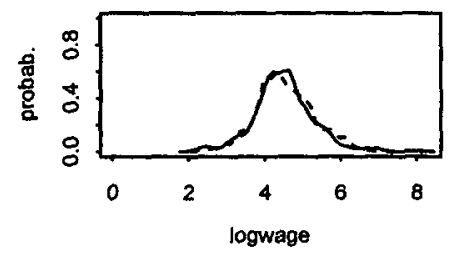


Figure 2: Comparisons of Distributions of Real Wages by groups, Argentina __ $1988--1997$ age $<25$ yrs.

primary

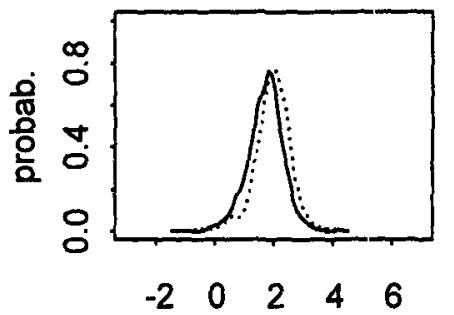

logwage

$25=<$ age $<45$

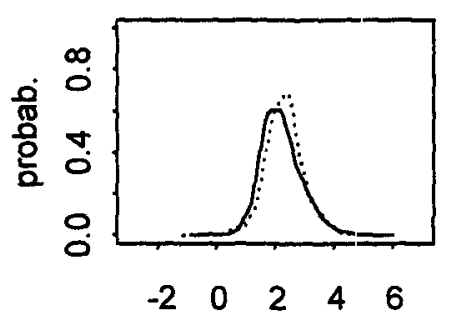

logwage

age $>=45$

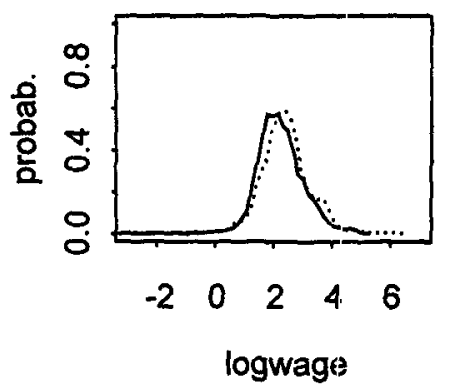

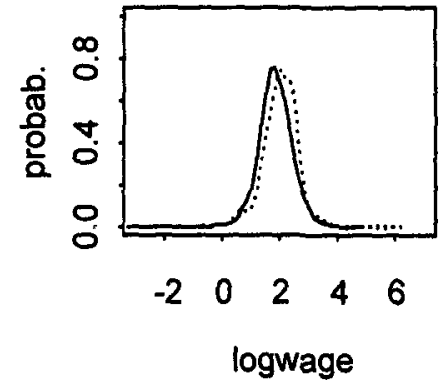

secondary

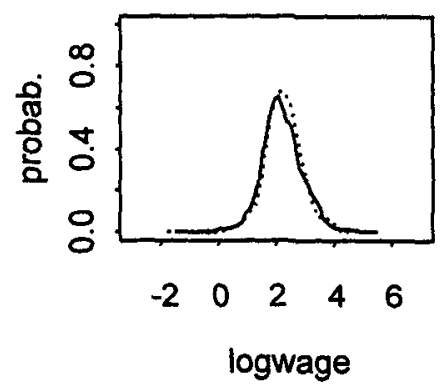

higher education

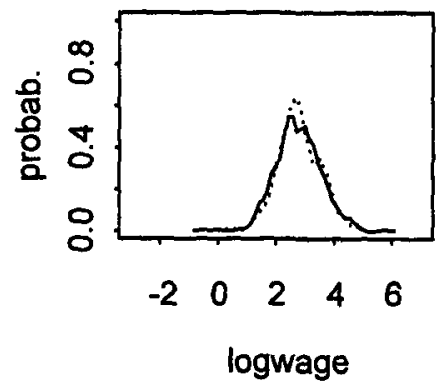

unskilled

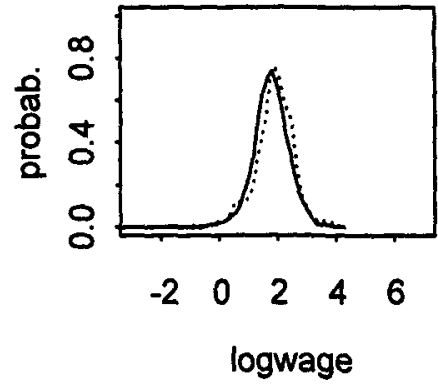

skilled

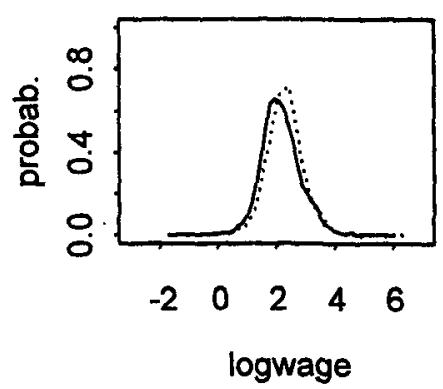

professionals

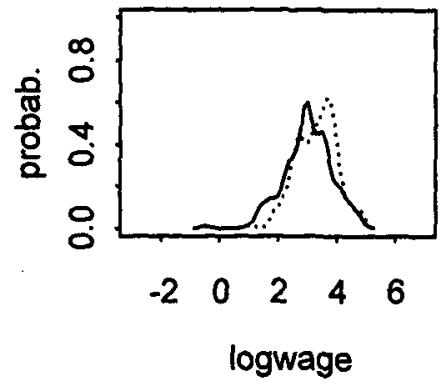


Figure 3: Comparisons of Distributions of Real Wages by groups, Brazil __ $1989-1995$ age $<25$ yrs.

primary

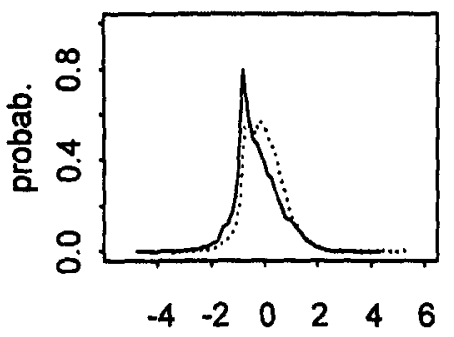

logwage

$25=<$ age $<45$

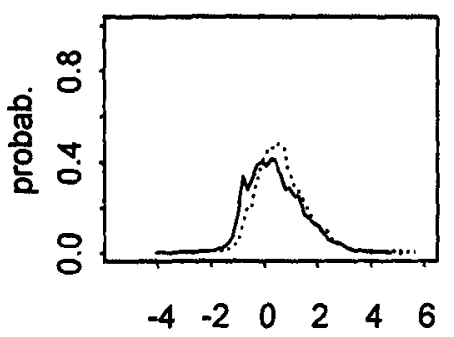

logwage

age $>=45$

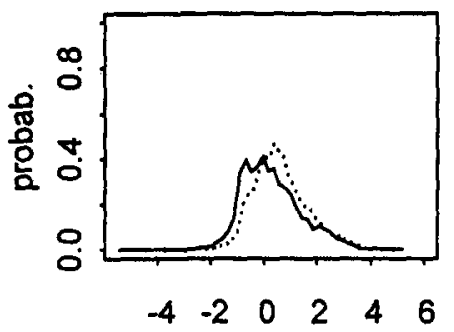

logwage

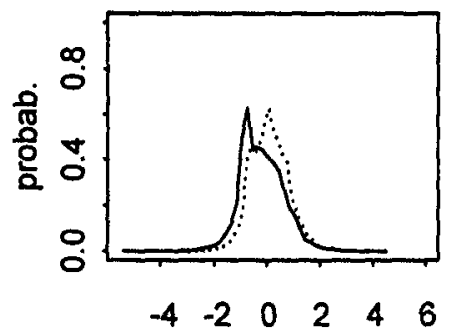

logwage

secondary

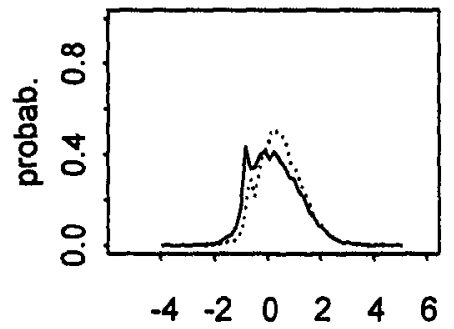

logwage

higher education

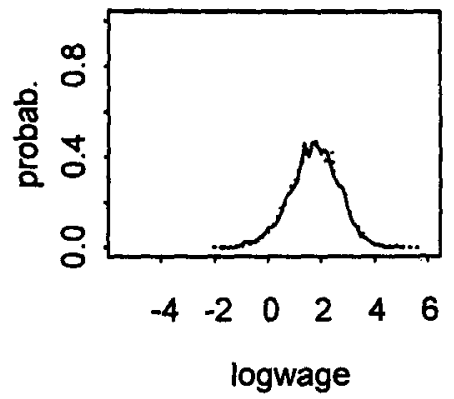

blue collar

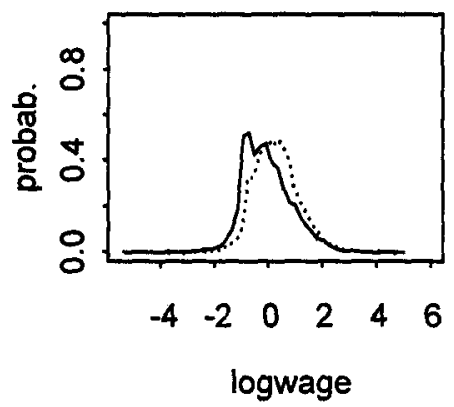

white collar

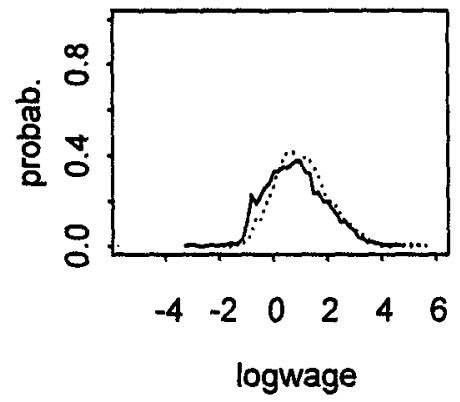

professionals

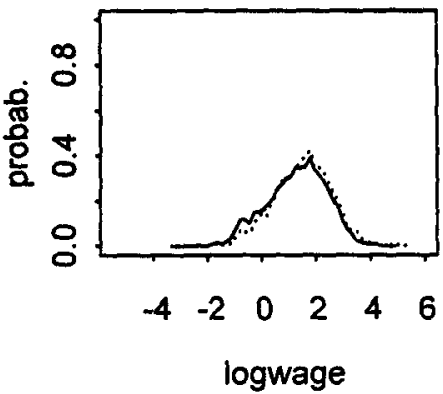


Figure 3: Comparisons of Distributions of Real Wages by groups, Costa Rica

$1989-1995$

agle $<25$ yrs.

primary

blue collar
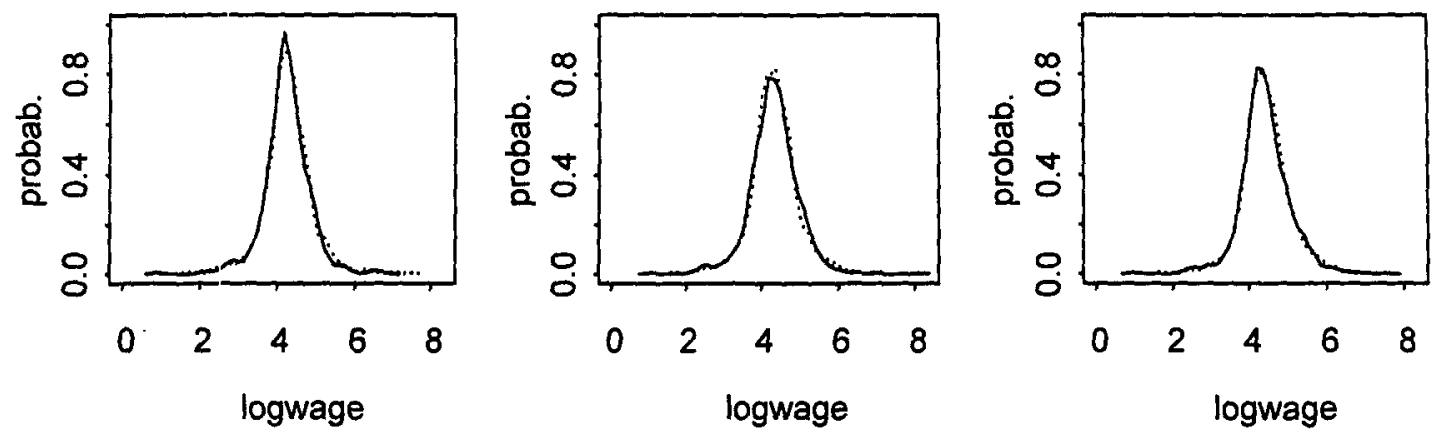

$25=<$ age $<45$

secondary

white collar
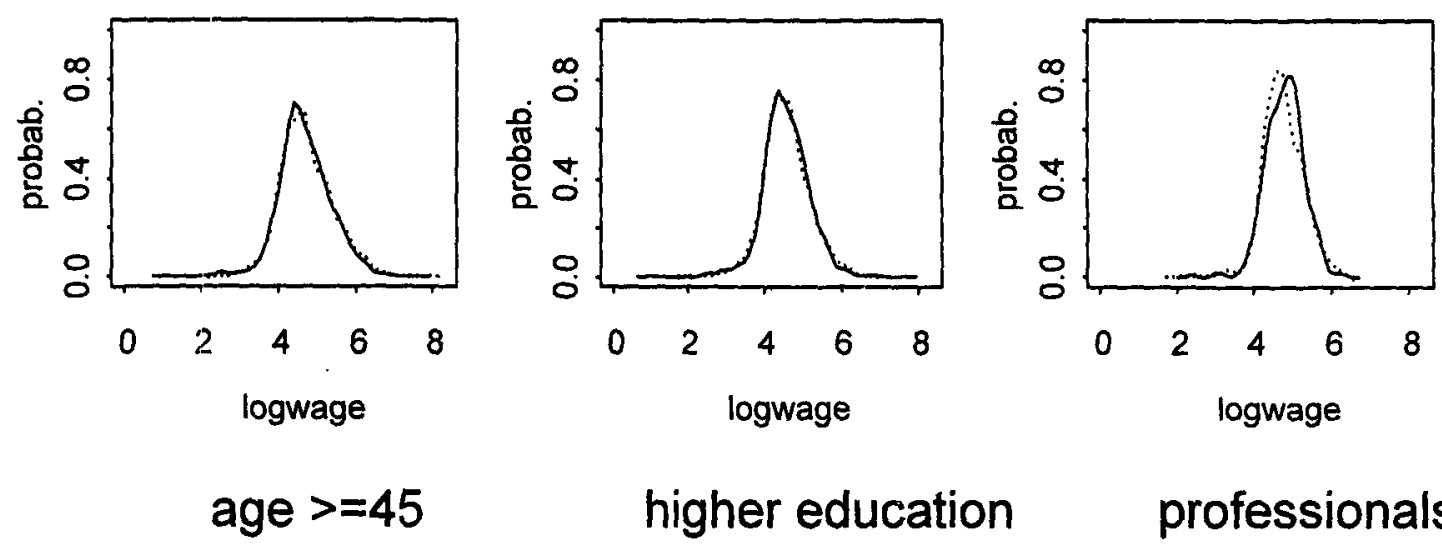

higher education

professionals
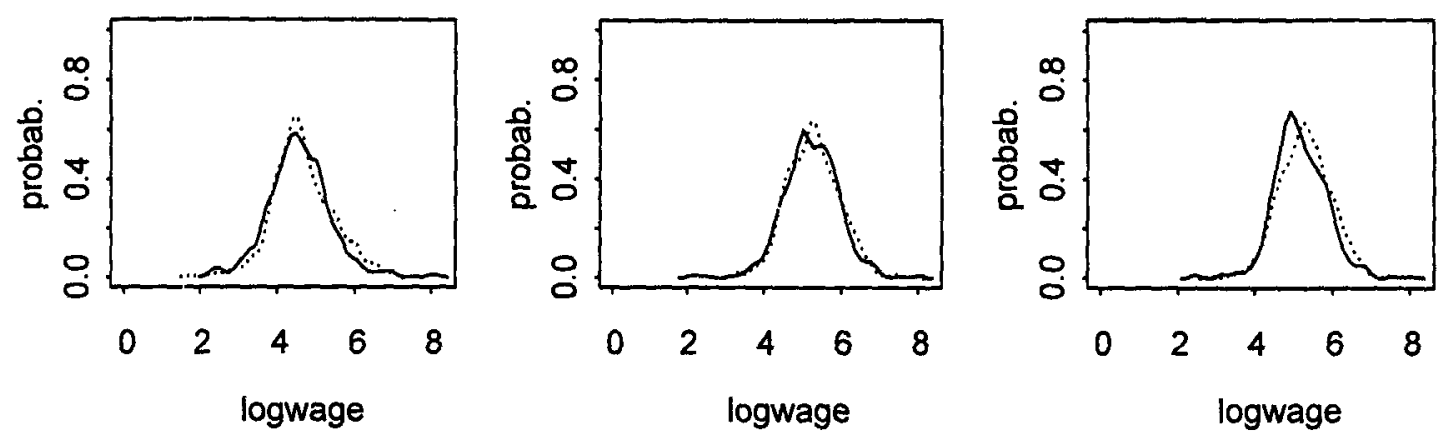
TABLE 5: Change in Quantile Wage Differentials, Men (\% per year)

\begin{tabular}{|c|c|c|c|c|c|c|c|c|c|c|c|c|c|c|c|c|c|c|}
\hline $97 / 88$ & & & Aroen & & & & $95 / 89$ & & Brazil & & & & $95 / 89$ & & Cnsta I & & & \\
\hline quantiles & 0.05 & 0.1 & 0.25 & 0.5 & 0.75 & 0.9 & 0.05 & 0.1 & 0.25 & 0.5 & 0.75 & 0.9 & 0.05 & 0.1 & 0.25 & 0.5 & 0.75 & 0.9 \\
\hline Intercept & 3.00 & 4.44 & 3.74 & 2.32 & 0.51 & -0.23 & 4.00 & 3.71 & 3.43 & 0.23 & 0.35 & -1.56 & 0.63 & 2.76 & 7.56 & 3.45 & -3.24 & -2.19 \\
\hline primal & 0.84 & -0.25 & 2.43 & 1.79 & 1.56 & 2.51 & 2.95 & 1.72 & 2.01 & 2.74 & 2.03 & 3.45 & -4.87 & -1.81 & -1.69 & -1.08 & 4.08 & 4.33 \\
\hline prima2 & -0.04 & -0.34 & 0.75 & 0.95 & 0.77 & 1.43 & 3.51 & 2.39 & 2.74 & 2.14 & 0.61 & 2.20 & 1.59 & -1.57 & -1.77 & -0.49 & 5.65 & 5.23 \\
\hline prima3 & 1.11 & -0.40 & 1.01 & 0.58 & 0.28 & 1.68 & 4.08 & 3.15 & 4.16 & 3.17 & 1.68 & 3.71 & -0.84 & -0.41 & 0.00 & -0.44 & 5.41 & 10.27 \\
\hline secunl & 0.60 & 0.45 & 0.52 & -0.13 & -0.64 & 0.78 & 3.63 & 2.18 & 2.72 & 2.37 & 0.22 & 0.70 & -0.49 & -1.46 & -2.32 & -1.25 & 6.33 & 5.74 \\
\hline secun2 & -0.96 & -1.12 & 0.15 & -0.24 & -0.49 & -0.69 & 4.06 & 1.99 & 1.99 & 0.89 & -1.24 & -0.02 & 0.30 & -2.32 & -2.41 & -1.57 & 5.06 & 5.25 \\
\hline secun 3 & 3.69 & -0.07 & 0.78 & -0.21 & -0.46 & 1.27 & 2.60 & 1.30 & 1.15 & -0.05 & -1.93 & -0.83 & -1.74 & -1.97 & -3.61 & -2.54 & 2.01 & 3.69 \\
\hline univl & -0.09 & 0.51 & 1.63 & 0.56 & 0.73 & 2.24 & -0.64 & -1.20 & -1.40 & -1.53 & -2.63 & 0.65 & 3.57 & 1.83 & -0.15 & 2.66 & 5.50 & 4.73 \\
\hline univ2 & -1.79 & -1.51 & -1.49 & -1.97 & -2.01 & -0.30 & -0.15 & -0.67 & -1.10 & -0.97 & -1.48 & -0.48 & 1.79 & -0.17 & -2.00 & -2.38 & 2.83 & 6.13 \\
\hline manuf & 0.19 & 1.47 & 0.03 & 0.62 & 2.12 & 0.84 & -0.36 & 0.23 & 0.08 & 1.35 & 1.24 & 2.11 & 1.33 & 0.98 & -1.45 & 0.17 & 2.01 & -0.12 \\
\hline const & 1.81 & 4.44 & 3.18 & 4.59 & 6.58 & 4.19 & 0.22 & 1.28 & 1.19 & 3.71 & 3.69 & 3.98 & -0.05 & -0.54 & -0.84 & 1.28 & 3.77 & 4.80 \\
\hline retail & -1.14 & 0.08 & -0.14 & 0.84 & 2.18 & 0.68 & -0.51 & 0.35 & 0.34 & 2.07 & 2.33 & 3.35 & 1.19 & 0.18 & -1.24 & -0.77 & -0.05 & -1.19 \\
\hline serv1 & -0.44 & 1.70 & -0.13 & 0.77 & 2.32 & 0.19 & -1.91 & -0.23 & -1.60 & 0.27 & 0.59 & 1.08 & 0.34 & -0.25 & -1.36 & -0.43 & 1.21 & 1.88 \\
\hline busi & & & & & & & -0.51 & -0.31 & -0.02 & 0.58 & 1.10 & 2.12 & & & & & & \\
\hline socia & 3.44 & 2.35 & 2.05 & 2.27 & 2.82 & 1.10 & -1.08 & 0.12 & 1.08 & 4.06 & 5.63 & 6.80 & 2.74 & 0.23 & -0.48 & 0.71 & 2.43 & 1.53 \\
\hline other & -1.50 & 0.32 & 0.08 & 1.28 & 3.30 & 1.33 & 0.32 & 1.05 & 1.08 & 2.77 & 2.12 & 2.54 & 2.66 & 0.13 & -0.70 & 0.61 & 2.60 & 1.26 \\
\hline public & 3.23 & 2.51 & 1.53 & 1.98 & 4.04 & 2.11 & -0.13 & 0.47 & 0.35 & 3.69 & 3.69 & 5.67 & -2.16 & -0.97 & -2.12 & -1.63 & -0.12 & -0.65 \\
\hline agric & & & & & & & & & & & & & 1.24 & 0.13 & -1.97 & -1.19 & -1.84 & -1.16 \\
\hline unskilled & -2.85 & -2.79 & -2.68 & -1.60 & -1.29 & -0.46 & -1.22 & -0.67 & -0.36 & 0.58 & 0.42 & -1.02 & 1.59 & -0.30 & -1.22 & -1.71 & -1.80 & -3.41 \\
\hline skilled & -1.61 & -2.61 & -2.58 & -1.77 & -1.79 & -1.72 & -1.22 & -1.14 & -0.88 & 0.68 & 0.71 & -0.35 & 0.42 & 0.20 & -1.48 & -2.44 & -2.21 & -4.07 \\
\hline info & -0.19 & -0.27 & 0.20 & 0.56 & 0.35 & 1.49 & 2.99 & 1.70 & 0.94 & 0.92 & 1.14 & 2.22 & 0.71 & -0.35 & -1.22 & -0.62 & -0.25 & 1.01 \\
\hline self & -0.95 & -1.35 & -1.46 & -0.58 & -0.02 & 0.22 & -1.25 & -1.05 & -1.11 & -1.20 & -1.36 & -1.06 & -0.23 & -1.37 & -1.91 & -1.88 & 0.25 & -0.36 \\
\hline married & 0.35 & 1.02 & -0.10 & -0.07 & -0.32 & -0.38 & & & & & & & 0.94 & 3.92 & 0.27 & 0.13 & 1.81 & 0.77 \\
\hline c.union & -0.09 & 1.22 & 0.00 & -0.58 & -1.30 & -1.50 & & & & & & & 1.51 & 3.01 & -1.34 & -1.20 & -0.73 & -1.05 \\
\hline head & -1.25 & -1.09 & -0.26 & -0.40 & -0.30 & -0.32 & -1.05 & -1.54 & -1.57 & -2.13 & -2.32 & -2.58 & -1.50 & -2.26 & 0.58 & 1.14 & -1.25 & 0.47 \\
\hline black & & & & & & & 0.68 & 0.40 & 0.22 & 0.85 & 0.70 & 0.51 & & & & & & \\
\hline mulato & & & & & & & 0.32 & 0.39 & 0.70 & 1.12 & 1.55 & 0.91 & & & & & & \\
\hline asian & & & & & & & -2.63 & 0.30 & 1.15 & 3.85 & 2.52 & 4.06 & & & & & & \\
\hline reg2 & & & & & & & 0.22 & 0.07 & -0.80 & -1.00 & -1.05 & -0.99 & -1.48 & -1.03 & -0.94 & -0.69 & 0.49 & 0.87 \\
\hline reg3 & & & & & & & -1.46 & -0.91 & -1.50 & -1.34 & -1.13 & -0.18 & -0.33 & 0.25 & -0.88 & 0.56 & -0.86 & -2.72 \\
\hline reg4 & & & & & & & & & & & & & -3.29 & -2.12 & -1.84 & 0.25 & -0.46 & 0.37 \\
\hline reg5 & & & & & & & & & & & & & -3.20 & -2.00 & -1.77 & -0.67 & -1.40 & 0.07 \\
\hline $\exp 1$ & -0.04 & -0.68 & -0.37 & -0.30 & 0.13 & 0.19 & & & & & & & & & & & & \\
\hline $\exp 2$ & 1.72 & 0.53 & 0.66 & 1.11 & 0.83 & 1.63 & & & & & & & & & & & & \\
\hline exp3 & 0.59 & 0.56 & 0.60 & 0.15 & 0.02 & 0.90 & & & & & & & & & & & & \\
\hline
\end{tabular}

Note: a negative (positive) sign indicates an increase (a reduction) in the gap, ie., a relative wage deterioration (improvement). 


\section{References}

Arango, C. and W. Maloney, 1999, "Labor Markets, Employment and Poverty in Argentina", World Bank, mimeo.

Arias, Omar, 1999. Marginalization of Men in Argentina: Evidence from Changes in Wage Distributions, World Bank, mimeo.

Arias, O., K. Hallock and W. Sosa, 1999, "Heterogeneity in the Returns to Schooling: Instrumental Variables Quantile Regression using Twins Data", University of Illinois at UrbanaChampaign, mimeo.

Baer, Werner, 1995, The Brazilian Economy: Growth and Development, $4^{\text {th }}$ edition, Praeger Publishers, Westport, Connecticut.

Barker, G., 1998, "Boys in the Hood, Boys in the Bairro: Exploratory Research on Masculinity, Fatherhood and Attitudes Toward Women Among Low Income Young Men in Chicago, SA and Rio de Janeiro, Brazil". Seminar on Men, Family Formation and Reproduction, Buenos Aires, Argentina.

Berman, E., J. Bound and S. Machin, 1997, "Implications of Skill-Biased Technological Change: International Evidence". NBER Working Paper 6166, 40 pages.

Bouillon, C., A. Legovini and N. Lustig, 1999, "Can Education Explain Inequality Changes in Mexico", Mimeo, The Inter-American Development Bank.

Buchinsky, Moshe, 1994, "Changes in the U.S. Wage Structure 1963-1987: An Application of Quantile Regression," Econometrica, March, 62 (2), pp. 405-58.

Cespedes, S. and V. H. Jimenez, 1994, "Apertura Comercial y Mercado Laboral en Costa Rica". Academia de Centroamérica : Centro Internacional para el Desarrollo Económico, San José, Costa Rica. 162 pages.

Chamon, S., 1998, "Rising Wages and Declining Employment: The Brazilian Manufacturing Sector in the 90s". IPEA, Texto Para Discussao No. 552. 19 pages.

Cragg, M. and M. Epelbaum, 1996, "Why Has Wage Dispersion Grown in Mexico? Is it the Incidence of Reforms or the Growing Demand for Skills", Journal of Development Economics, Vol 51, pp. 99-116.

Edwards, Sebastian, 1995, Crisis and Reform in Latin America: From Despair to Hope. World Bank, Oxford University Press. 364 pages. 
Ferreira, F. and R. Paes de Barros, 1999, "The Slippery Slope: Explaining the Increase in Extreme Poverty in Urban Brazil: 1976-1996", mimeo, World Bank.

Heckman, James, 1979, "Sample Selection Bias as a Specification Error", Econometrica, 47, pp. 153-161.

Inter-American Development Bank, 1997, Latin America After a Decade of Reforms. Economic and Social Progress in Latin America, Baltimore Maryland: John Hopkins University Press. 295 pages.

Kennedy, Paul, 1981, "Estimation with Correctly Interpreted Dummy Variables in Semilogarithmic Equations", American Economic Review, 71 (4), pp. 801.

Koenker, Roger, 1994, "Confidence Intervals for Regression Quantiles," In: Mandl, P. and Huskova, M. eds, Asymptotic Statistics: Proceedings of the 5th Prague Symposium, PhysicaVerlag, Heidleberg, 1994.

Koenker, R., and G. Bassett, 1978, "Regression Quantiles", Econometrica, January, 46 (1), pp. 126.

Koenker, R. and Portnoy, S., 1997, "Quantile Regression," Office of Research Working Paper \#97-0100, College of Commerce and Business Administration, University of Illinois at UrbanaChampaign

Korenman, S. and D. Neumark, 1991, "Does Marriage Really Make Men More Productive?", Journal of Human Resources, 26 (2), pp. 282-307.

Leamer, Edward E., 1997, “U.S. Wages, Technological Change and Globalization”, mimeo.

Maloney, William, 1998, “Are Labor Markets in Developing Countries Dualistic?", The World Bank, Policy Research Working Paper 1941.

Maloney, William, 1998, "The Structure of Labor Markets in Developing Countries: Times Series Evidence on Competing Views", The World Bank, Policy Research Working Paper 1940.

Maloney, W. and E. P. Ribeiro, 1999, "Efficiency Wage and Union Effects in Labor Demand and Wage Structure in Mexico", mimeo.

Machado, J. and Mata J., 1999, "Sources of Increased Wage Inequality”, mimeo.

Montenegro, C., 1999, "The Structure of Wages in Chile 1960-1996: An Application of Quantile Regression", Estudios de Economia, Vol. 25-No. 1, pags. 71-97. 
Mwabu, G., and T. P. Schultz, 1996,"Education Returns Across Quantiles of the Wage Function: Alternative Explanations for Returns to Education by Race in South Africa", American Economic Review, 86 (2), May, pp. 335-339.

Pessino, Carola, 1997, "The Labor Market During The Economic Transition." In Labor Markets in Latin America, Combining Social Protection with Market Flexibility. S. Edwards and N. Lusting, editors. Brookings Institution Press, Washington, DC. pp. 151-200.

Robins, Donald J., 1997, "Hos Hits Facts: Facts Win: Evidence on Trade and Wages in the Developing World", mimeo.

Saavedra, Luz, 1999, "Wage Inequality in Latin American Labor Markets”, mimeo.

Ruprah, I. and L. Marcano, 1999, "Digging a Hole: Poverty and Income Inequality in Venezuela: 1979-1997”, Mimeo, Inter-American Development Bank.

Velez, C.E., A. Kugler and C. Bouillon, 1999, "The Reversal of Inequality Gains in Urban Colombia, 1978-1995: A combination of Persistent and Fluctuating Forces", mimeo, InterAmerican Development Bank.

Wood, Adrian, 1997, "Openness and Wage Inequality in Developing Countries: The Latin American Challerige to East Asian Conventional Wisdom", World Bank Economic Review, 11 (1), pp. 33-58.

World Bank (1996), "Argentina, The Convertibility Plan: Assessment and Potential Prospects". Vols 1-2. Report No. 15402-Ar.

World Bank (1995), “Argentina's Poor: A Profile”. Report No. 13318-Ar. 


\section{APPENDIX I: Definitions of Dummy Variables}

Informal: Informal salaried info are defined as men working in small firms (less than 6 workers) without work insurance and retirement plan coverage (Argentina) or without social security coverage from employers (Costa Rica), or those without a signed federal card -excluding public servants- (Brazil). The self-employed self are those that report to be "cuenta propias".

Age-Education: Age-education dummies are defined as follows: $E d u c i=$ educ and agei where educ refers to the last level of education achieved (prima= some or complete primary; secun = some or complete secondary education; univ= some or complete college), and age refers to the i- $t h$ age group (age 1:=15-25 years, age2: $25-45$ years, age3: $45-70$ years). For example, secunl corresponds to workers with some or complete secondary education and age 15-25.

Tenure in the occupation (Argentina): less than 1 year in the current occupation (exp1), between 1 and $5(\exp 2)$ years, between 5 and $10(\exp 3)$ years and more than 10 years $(\exp 4)$.

Industry: These dummies are manuf, const, retail, serv1, serv2, socia, pub and other. Manuf refers to men working in the production of food, beverages, cigarettes, textiles, clothing, chemical and metallic products, and other manufacturing; const to construction jobs; retail to jobs on commerce (including restaurants and hotels); serv1 to jobs in utilities, transportation and communication; serv2 to jobs in finance, real state and professional services; socia to those working in social services, excluding public social services; $p u b$ to jobs in public administration, defense and public social services (Argentina and Brazil), or to jobs in the public sector including the descentralized government (Costa Rica). Finally, other is a residual dummy that groups jobs in all other sectors (agriculture, mining and personal services). In Brazil available survey data allows to identify business professional services jobs separately (busi dummy) from finance and real estate.

Regional: In Brazil three regional dummies were included: reg1 (southeast), reg2 (south), and reg3 (northeast). The southeast dummy includes Minas Gerais, Rio de Janeiro and Sao Paulo, the south dummy includes Parana and the northeast region includes Bahia, Ceara, Pernambuco and Maranhao. In Costa Rica we included five regional dummies: reg1 (Metropolitan area), reg2 (rest of Central Region), reg3 (Chorotega and Brunca), reg4 (Central Pacific) and reg5 (Atlantic and Northern Huertar regions).

Occupations: Each occupational dummy groups men according to three different levels of skills based on self-reported occupations: profe, skilled and unskilled. The first dummy groups men that reported to be working in jobs that require professional qualifications, skilled groups those that reported to be working in administrative (white collar) jobs, and unskilled refers to men that reported to be working in jobs of low qualification. In Costa Rica a dummy for a few workers reporting occupations in agriculture (agric) was included.

Miscelaneous: The dummies for marital status married and consensual union c.union as well as the race dummies for Brazil (asian, black, mulato, white) are based on self-reports. The household heads dummy head refer to men who report to be heads of households with at least two members. 


\section{APPENDIX II: Quantile Regression}

In this section we present some basic results on the quantile regression methods used in this work. ${ }^{41}$ Consider the following linear model:

$$
Y=X \beta+u
$$

where $u$ is a vector of independent error terms whose $i$-th component has an unspecified distribution function $F_{i}$. Given the usual conditional orthogonality assumption on the error term, Ordinary Least Squares regression provides a model for the conditional mean of $Y$ given by:

$$
E[Y / X]=X \hat{\beta}
$$

In the special case of iid errors this Least Squares estimate together with some measure of dispersion would usually provide a complete characterization of (1). ${ }^{42}$ Nevertheless, it is increasingly recognized that the iid linear model is not well suited to analyze problems which involve very heterogeneous populations.

Quantile regressions provide a very useful alternative by providing models for different percentiles of $F_{y / x}$, the conditional distribution of $Y$ given $X$. For (1) the $\tau$-th conditional quantile of $Y$ is given by:

$$
Q_{\tau}=\mathrm{X} \beta(\tau)
$$

where the orthogonality condition on $u$ is now assumed for $\mathrm{Q}_{\tau}(u \mid \mathrm{X})$, that is, the $\tau$-th conditional quantile of the error term is assumed to be zero. This gives rise to a family of (quantile) regression curves, one for each $\tau$, which provide a more complete characterization of the relationship between $Y$ and $X$. Quantile regression also offers the usual robustness properties associated with ordinary sample quantiles, particularly robustness to outlying observations in $Y$. In the case of the iid linear model the conditional quantile functions given in (3) will be parallel vertical displacements of one another, and only robustness arguments would lead one to prefer alternative estimators of location other than OLS. The most interesting case arises when the estimated $\beta(\tau)$ coefficients differ systematically across $t$ s, suggesting that the marginal effect of a particular explanatory variable varies across different quantiles of the conditional distribution of $Y$.

Estimation of the $\beta(\tau)$ coefficients known as "regression quantiles" is based on a sample of $n$ observations of $Y$ and $p$ explanatory variables collected in the matrix $X$. It can be shown that estimates of $\beta(\tau)$ can be obtained as solutions to the following linear programming problem:

$$
\min _{(\beta, \mathrm{u}, \mathrm{v}) \in R^{p} \times R_{+}^{2 n}}\left[\tau 1^{\prime}{ }_{\mathrm{n}} u+(1-\tau) 1^{\prime}{ }_{\mathrm{n}} v \mid X \beta+u-v=Y\right] .
$$

where $1_{n}^{\prime}$ is an $n$ vector of ones and $u$ and $v$ are the positive and negative parts of the residual vector. In practice, an adaptation of the Barrodale-Roberts algorithm for the least absolute deviation problem makes computation now comparable to least squares methods for reasonable

${ }^{41}$ See Koenker and Portnoy (1997) for a recent comprehensive overview of the topic.

${ }^{42}$ If additionally, $F_{i}$ is assumed to be Gaussian, then OLS yields the optimal estimator of location for the linear model (1). 
size data sets. Substantial computational time improvement for very large data sets has recently been accomplished through interior point methods (Koenker and Portnoy (1997)).

Inference on the $\beta(\tau)$ 's can be based on the following result. Let $b_{n}=\left(b_{n}\left(\tau_{1}\right), \ldots b_{n}\left(\tau_{m}\right)\right)$ be a pm vector of $p$ estimated regression quantile coefficients for $m$ different quantiles based on a sample of $n$ iid observations; and let $\beta$ be its population counterpart. Under some regularity conditions Koenker and Basset (1978) showed that:

$$
\ln \left(b_{n}-\beta\right) \rightarrow N\left(0, \Omega \otimes \mathrm{Q}_{0}^{-1}\right)
$$

where $\Omega$ is a $m \times m$ matrix with typical element:

$$
\omega_{i j}=\left(\min \left(\tau_{i}, \tau_{j}\right)-\tau_{i} \tau_{j}\right) /\left[f\left(F^{-1}\left(\tau_{i}\right)\right) f\left(F^{-1}\left(\tau_{j}\right)\right)\right]
$$

$\mathrm{Q}_{0}=$ plim $\mathrm{n}^{-1}\left(X^{\prime} X\right)$, a positive definite matrix, and $\otimes$ denotes the Kronecker product. Confidence intervals can be easily constructed based on this result. General linear hypothesis like $\mathrm{H}_{0}: H \beta=h$ can be tested using the following Wald-type statistic:

$$
T_{n}=\left(H b_{n}-h\right)^{\prime}\left[H\left(\Omega \otimes\left(X^{\prime} X\right)^{-1}\right) H^{\prime}\right]^{-1}\left(H b_{n}-h\right)
$$

which under the null hypothesis has a $\chi^{2}$ distribution with $\operatorname{rank}(H)$ degrees of freedom. This approach requires the estimation of the nuisance parameter $1 / \mathrm{f}\left(\mathrm{F}^{-1}(\tau)\right.$ ) (called sparsity) which measures the inverse of the density of the observations around the $\tau$-th quantile. This is usually accomplished based on estimates of the empirical quantile function constructed from residuals of the $\tau$-th quantile regression and using smoothing techniques.

An alternative approach to inference that takes advantage of the quantile regression formulation can be based on rank tests. These tests are robust to outliers in $Y$ and are asymptotically distribution free since they do not require the estimation of nuisance parameters depending on the error distribution, and are not more complicated to compute than those based on sparsity estimation. ${ }^{43}$. Let $X=\left[1: X_{1}: X_{2}\right]$ and suppose we are interested in testing the linear hypothesis $\mathrm{H}_{0}$ : $\beta_{2}=0$ vs $\mathrm{H}_{0}: \beta_{2} \neq 0$. The following statistic:

$$
\mathrm{W}=\left(\mathrm{Y}_{\mathrm{r}}^{\prime} \mathrm{M} \mathrm{X} \mathrm{X}_{2}\left(\mathrm{X}_{2}^{\prime} \mathrm{M} \mathrm{X}_{2}\right)^{-1} \mathrm{X}_{2}{ }^{\prime} \mathrm{M} \mathrm{Y}_{\mathrm{r}}\right) / \mathrm{A}
$$

has an asymptotic $\chi^{2}$ (q) distribution under the null hypothesis, where $Y_{r}$ is an estimated vector of ranks of the observations, $M=I-X_{1}\left(X_{1}^{\prime} X_{1}\right)^{-1} X_{1}^{\prime}$ and $\mathrm{A}$ is a quantity that does not depend on the distribution of the errors. Visual inspection suggests that the rank-based test is very similar to Lagrange multiplier tests where the $y_{i}$ 's play the role of the square residuals. The estimation of the ranks vector can be obtained as a by-product of the computation of the regression quantiles for the linear model under the restricted model. Based on the well known duality between hypothesis testing and construction of confidence intervals, a test to evaluate the significance of a single variable can be inverted to obtain a confidence interval for each coefficient. ${ }^{44}$ We used this approach to construct confidence intervals for the vector of quantile regression coefficients.

\footnotetext{
${ }^{43}$ Since we do not attempt to summarize the theory of such tests here we refer to Koenker and Portnoy (1997) and Koenker (1994) for a review and relevant references.

${ }^{44}$ Koenker (1994) discusses in detail computational and theoretical advantages as well as montecarlo results in favor of these tests.
} 



\section{Policy Research Working Paper Series}

\begin{tabular}{|c|c|c|c|c|}
\hline & Title & Author & Date & $\begin{array}{l}\text { Contact } \\
\text { for paper }\end{array}$ \\
\hline WPS2717 & $\begin{array}{l}\text { Bridging the Economic Divide within } \\
\text { Nations: A Scorecard on the } \\
\text { Performance of Regional Development } \\
\text { Policies in Reducing Regional Income } \\
\text { Disparities }\end{array}$ & $\begin{array}{l}\text { Raja Shankar } \\
\text { Anwar Shah } \\
t\end{array}$ & November 2001 & $\begin{array}{l}\text { A. Santos } \\
31675\end{array}$ \\
\hline WPS2718 & $\begin{array}{l}\text { Liberalizing Basic } \\
\text { Telecommunications: The Asian } \\
\text { Experience }\end{array}$ & $\begin{array}{l}\text { Carsten Fink } \\
\text { Aaditya Mattoo } \\
\text { Randeep Rathindran }\end{array}$ & November 2001 & $\begin{array}{l}\text { R. Simms } \\
37156\end{array}$ \\
\hline WPS2719 & $\begin{array}{l}\text { Is There a Positive Incentive Effect } \\
\text { from Privatizing Social Security? } \\
\text { Evidence from Latin America }\end{array}$ & Truman G. Packard & November 2001 & $\begin{array}{l}\text { T. Packard } \\
89078\end{array}$ \\
\hline WPS2720 & $\begin{array}{l}\text { International Migration and the Global } \\
\text { Economic Order: An Overview }\end{array}$ & Andres Solimano & November 2001 & $\begin{array}{l}\text { A. Bonfield } \\
31248\end{array}$ \\
\hline WPS2721 & $\begin{array}{l}\text { Implications for South Asian Countries } \\
\text { of Abolishing the Multifibre } \\
\text { Arrangement }\end{array}$ & $\begin{array}{l}\text { Sanjay Kathuria } \\
\text { Will Martin } \\
\text { Anjali Bhardwaj }\end{array}$ & November 2001 & $\begin{array}{l}\text { M. Kasilag } \\
39081\end{array}$ \\
\hline WPS2722 & $\begin{array}{l}\text { Japan's Official Development } \\
\text { Assistance: Recent Issues and } \\
\text { Future Directions }\end{array}$ & $\begin{array}{l}\text { Masahiro Kawai } \\
\text { Shinji Takagi }\end{array}$ & November 2001 & $\begin{array}{l}\text { J. Mendrofa } \\
81885\end{array}$ \\
\hline WPS2723 & $\begin{array}{l}\text { Using Development-Orineted Equity } \\
\text { Investment as a Tool for Restructuring } \\
\text { Transition Banking Sectors }\end{array}$ & Helo Meigas & November 2001 & $\begin{array}{l}\text { S. Torres } \\
39012\end{array}$ \\
\hline WPS2724 & $\begin{array}{l}\text { Tropical Bubbles: Asset prices in } \\
\text { Latin America, 1980-2001 }\end{array}$ & $\begin{array}{l}\text { Santiago Herrera } \\
\text { Guillermo Perry }\end{array}$ & November 2001 & $\begin{array}{l}\text { R. Izquierdo } \\
84161\end{array}$ \\
\hline WPS2725 & $\begin{array}{l}\text { Bank Regulation and Supervision: } \\
\text { What Works Best? }\end{array}$ & $\begin{array}{l}\text { James R. Barth } \\
\text { Gerard Caprio Jr. } \\
\text { Ross Levine }\end{array}$ & November 2001 & $\begin{array}{l}\text { A. Yaptenco } \\
38526\end{array}$ \\
\hline WPS2726 & $\begin{array}{l}\text { Applying the Decision Rights } \\
\text { Approach to a Case of Hospital } \\
\text { Institutional Design }\end{array}$ & Florence Eid & November 2001 & $\begin{array}{l}\text { A. Santos } \\
31675\end{array}$ \\
\hline WPS2727 & $\begin{array}{l}\text { Hospital Governance and Incentive } \\
\text { Design: The Case of Corporatized } \\
\text { Public Hospitals in Lebanon }\end{array}$ & Fiorence Eid & November 2001 & $\begin{array}{l}\text { A. Santos } \\
31675\end{array}$ \\
\hline WPS2728 & Evaluating Emergency Programs & William F. Maloney & December 2001 & $\begin{array}{l}\text { A. Pillay } \\
88046\end{array}$ \\
\hline WPS2729 & $\begin{array}{l}\text { International Evidence on the Value } \\
\text { of Product and Geographic Diversity }\end{array}$ & Luc Laeven & December 2001 & $\begin{array}{l}\text { R. Vo } \\
33722\end{array}$ \\
\hline
\end{tabular}




\section{Policy Research Working Paper Series}

Title

i WPS2730 Antidumping as Safeguard Policy

,

WPS2731 An Alternative Technical Education System in Mexico: A Reassessment of CONALEP

WPS2732 The Unbalanced Uruguay Round Outcome: The New Areas in Future WTO Negotiations

WPS2733 Trade Policy Reform and Poverty Alleviation

WPS2734 Agricultural Markets in Benin and Malawi: The Operation and Performance of Traders Exemptions and Evasion: An Empirical Ritva Reinikka Investigation of Uganda

WPS2736 Social Policy and Macroeconomics: F. Desmond McCarthy The Irish Experience

WPS2737 Mode of Foreign Entry, Technology Transfer, and Foreign Direct Investment Policy

WPS2738 Assisting the Transition from Workfare to Work: A Randomized Experiment

WPS2739 Poverty, Education, and Health in Indonesia: Who Benefits from Public Spending?
Author

Date

December 2001

J. Michael Finger

Francis $\mathrm{Ng}$

Sonam Wangchuk

Gladys Lopez-Acevedo

December 2001

J. Michael Finger Julio J. Nogues

Bernard Hoekman

Constantine Michalopoulos

Maurice Schiff

David Tarr

Marcel Fatchamps

December 2001

P. Kokila 33716

Bernard Gauthier

Contact for paper

R. Simms

37156

M. Geller 85155

December 2001

R. Simms 37156

R. Martin 39065

December 2001

H. Sladovich 37698

December 2001

J. Turner

81767

December 2001

R. Martin 39065

Marcelo Olarreaga

Kamal Saggi

Emanuela Galasso

December 2001

C. Cunanan 32301

Agustin Salvia

Peter Lanjouw Menno Pradhan

December 2001

P. Sader 33902

Haneen Sayed

Robert Sparrow 